\title{
HUKUK DEVLETI İDEALİNE FELSEFİ BİR BAKIŞ
}

\author{
Prof. Dr. Sururi AKTAŞ*
}

\begin{abstract}
ÖZET
$\mathrm{Bu}$ makalede hukuk devletinin kavramsal çözümlemesi yapılarak söz konusu kavramın içeriğini oluşturan bileşenlerin neler olduğu, çeşitli hukuk devleti idealleri açısından ortaya konulmaya çalışılmıştır. Ayrıca hukuk devletini besleyen ilke ve kuralların niteliği tartışılarak Hart'ın birincil kurallarikincil kurallar ayrımı açısından analiz edilmiştir. Hukuk devleti kavramının genel görünümleri olan biçimsel (prosedürel) hukuk devleti ve maddi hukuk devleti ayrımı yapılarak bu ayrımların hangi temel hukuk teorilerine denk düştüğü irdelenmiştir. Diğer yandan, ne tür bir hukuk devleti kavramının, bu idealden beklenen amacı gerçekleştireceği de tartışılmıştır. Hukuk devletinin biçimsel (prosedürel) ve kurumsal gereklerinin tek başına yetersizliği vurgulanarak bunlara hukuk devletinin maddi gereklerinin de eklenmesi zorunluluğu anlatılmaya çalışılmıştır. Hukuk devletinin kurumsal gerekleri genel olarak "biçimsel hukuk devleti" kategorisi içerisinde görülse de, çalışmanın sonuç bölümünde kurumsal gerekler ayrı bir kategoride değerlendirilerek, biçimsel, kurumsal ve maddi unsurları taşıyan bir hukuk devleti kavramı önerisinde bulunulmuştur.
\end{abstract}

Anahtar Kelimeler: Hukuk Devleti, Rechtsstaat, Yasacılık, Biçimsel Hukuk Devleti, Maddi Hukuk Devleti, Prosedürel Hukuk Devleti.

Erzincan Binali Yıldırım Üniversitesi Hukuk Fakültesi Hukuk Felsefesi ve Sosyolojisi Anabilim Dalı Öğretim Üyesi, saktas@erzincan.edu.tr, ORCID ID: 0000-0001-6513-0525 (Geliş Tarihi: 11.07.2019 - Kabul Tarihi: 22.11.2019). 


\title{
A PHILOSOPHICAL LOOK AT THE IDEAL OF THE RULE OF LAW
}

\begin{abstract}
In this article, after having made the conceptual analysis of the rule of law, the components of the concept of rule of law are tried to be explaned in terms of the ideals of different understandings of the rule of law. It is also discussed the nature of principles and rules of the concept of rule of law and analyzed in terms of Hart's primary rules-secondary rules distinction. The formal (procedural) and substantive conceptions of rule of law, as the general aspects of the rule of law, are examined. Besides, it is tried to examine the formal (procedurel) and substantive concepts of rule of law in terms of main legal theories. On the other hand it is disscussed what kind of the concept of rule of law will serve to the objective which is expected from this ideal. The deficiency and weakness of the formal (procedural) and institutional concepts of the rule of law are emphasized and tried to exhibit that some substantive requirements of rule of law should be added to the formal and institutional conceptions. The institutional requirements, which are generally deemed in the category of formal concept of rule of law, are considered as separate category in the conclusion of this paper. Accordingly in the conclusion of the article it is tried to propose a suggestion about the concept of the rule of law which contains formal, institutional and substantive elements.
\end{abstract}

Key Words: Rule Of Law, Rechtsstaat, Legalism, Formalist Conception of the Rule of Law, Proceduralist Conception of the Rule of Law, Substantive Conception of the Rule of Law. 


\section{I-KAVRAM OLARAK HUKUK DEVLETİ İDEALININN GÖRÜNÜMÜ}

Hukuk devleti (Rule of law, Rechtsstaat) kavramı, gerek hukuk biliminde ve gerekse mahkeme kararlarında sıkça kendisine başvurulan bir ölçüttür. Başvurulan kavram sözel olarak aynı olsa da, bundan farklı şeyler kastedilmiş olabilmektedir. Hukuk devleti kavramını, kararlarında ve çalışmalarında esas alanlar, benimsedikleri hukuk devleti idealine göre değerlendirmelerini yaparlar. Nasıl bir hukuk devletini benimsediğimiz, genel olarak hukuktan ne anladığımıza bağlıdır Kabul ettiğimiz hukuk teorisi genel olarak hukuk devleti anlayışımızı da belirler. Hukuk devletinden ne anlaşılması gerektiğine ilişkin çabalar, hukuk teorilerine ilişkin öğretilerle yakından alakalıdır². Anayasalar ve yasalar hukuk devletine göndermede bulunmalarına karşın, belirleyici ve tanımlayıcı bir içerik sunmazlar. Hukuk devletine içerik kazandırmaya dönük çabalar, öğreti tarafından yerine getirilir.

Öğretide hukuk devleti genelde ikili bir ayrıma tabi tutulur. Bu ayrım, "biçimsel anlamda hukuk devleti -maddi anlamda hukuk devleti" ş̧eklinde olabildiği gibi, "prosedürel hukuk devleti" ${ }^{4}$-maddi hukuk devleti";"; "araçsal (instrumental) hukuk devleti-maddi hukuk devleti ${ }^{6}$ " şeklinde de olabilmektedir. Biçimsel (prosedürel) hukuk devleti ve maddi hukuk devleti ayrımı en yaygın ve kabul gören ayrım olduğu için mahkemelerin bağımsızlığı gibi hukuk devletinin kurumsal gerekleri de genel olarak biçimsel (prosedürel) anlamda hukuk devleti içerisinde değerlendirilir. Biz de çalışmada yaygın kabule uygun olarak konuyu, biçimsel (prosedürel) hukuk devleti ve maddi hukuk

Craig, Paul (1997) "Formal and Substantive Conceptions of The Rule of Law: An Analytical Framework", Public Law, s. 487; Marmor, Andrei (2010) "The Ideal of the Rule of Law", A Companion to Philosophy of Law and Legal Theory, Patterson, Dennis, (Editor), Second Edition, Wiley-Blacwell, s. 667.

2 Gül, Cengiz (2010) İktidarın Sınırlandırılması ve Hukuk Devleti, Birinci Baskı, Ankara, Adalet Yayınevi, s. $208 \mathrm{vd}$

3 Nowacki, Josef (1969) “The Material and Formal Conceptions of the Rule of Law", Polish Round 3, s. 8187. Tamanaha, Brain Z. (2004) On The Rule Of Law: History, Politics, Theory, Cambridge University Press, s. 91; Craig, s. 467; Hatemi, Hüseyin (1989) Hukuk Devleti Öğretisi, 1. Baskı, İstanbul, İșaret Yayınları, s. 19; Ökçesiz, Hayrettin (1998a) "Hukuk Devleti", Hukuk Devleti, Ökçesiz, Hayrettin (Editör), Hukuk Felsefesi ve Sosyolojisi Arkivi 4, İstanbul, AFA Yayınc1lık s. 21-25; Uygur, Gülriz (2013) Hukuk Devletinde Hukukun Önünde Olmanın Anlamı, Prof. Dr. Erdal ONAR'a Armağan Cilt. II, Ankara, Ankara Üniversitesi Yayınları, s. 1156; Gül, s. 200.

4 Özcan, Mehmet Tevfik (2008) Modern Toplum ve Hukuk Devleti, 1. Baskı, İstanbul, XII Levha Yayını, s. 200; Rose, Jonathan (2004) “The Rule of Law in the Western World: An Overview”, Journal Of Social Philosophy, Vol. 35, No. 4, s. 459.

5 Özcan, s. 22; Rose, s. 461.

6 Radin, Margaret Jane (1989) "Reconsidering the Rule of Law", 69, Boston University Law Review, Vol 69, No:4, s. 783. 
devleti olarak ele alarak irdeledik. Ancak çalışmanın sonuç bölümünde bir öneri olarak hukuk devletinin kurumsal gereklerini zenginleştirerek önemlerinden dolayı ayrı bir kategoriye dâhil etmeyi tercih ettik.

Waldron hukuk teorisyenlerinin hukuk devleti idealiyle ilgili analizlerini, "biçimsel, prosedürel ve maddi” olmak üzere üç grupta toplar7. Waldron, biçimsel anlamda hukuk devletinin, yasaların geriye yürümezliği ve genelliği gibi birtakım biçimsel niteliklerle ilgili olduğunu belirtmekte ${ }^{8}$; prosedürel hukuk devletini ise, tarafsız ve bağımsız bir yargıç tarafından davaların görülmesi gibi yargılama usulüne ilişkin birtakım kurallara sahip devlet olarak görmektedir ${ }^{9}$ Maddi anlamda hukuk devleti, adalet ve insan haklarının korunması gibi yasaların içeriğine dönük bazı şartları içeriri ${ }^{10}$. Cass, hukuk devleti çeşitlerini ortaya koyarken, Pozitivist hukuk devleti kavramı, ahlaki nitelikli hukuk devleti (moral rule of law) ve bu iki aşırı ucun arasında bulunan çeşitli hukuk devleti teorilerinden söz eder ${ }^{11}$. Cass, hukuk devleti bakımından uç bir görüş olarak gördügü pozitivist hukuk devleti kavramını, yasa yapımı ve uygulamalarının birtakım şekli şartlara uyması zorunluluğunu gerektiren biçimsel anlamda hukuk devleti kavramıla aynı anlamda kullanır $^{12}$. Cass, diğer bir uçta ise, hukuk devleti anlayışını adaletle özdeş gören ahlaki hukuk devletini (moral rule of law) görür ${ }^{13}$. Cass, bu iki aşırı ucun arasında," istikrar, özgürlük, etkililik, fayda,..." gibi amaçlara hizmet eden hukuk devleti türlerini görür ${ }^{14}$.

Genel olarak pozitivist hukuk teorisi, biçimsel anlamda hukuk devleti anlayışına daha yakındır" ${ }^{15}$ Örneğin Hukuki pozitivistlerden Marmor’a göre, "hukuk devleti ideali" ile "iyi hukuk devleti idealini (rule of good law) birbirine karıştırmamak gerekir" ${ }^{16}$. Yazara göre "hukuk devleti", yasacılıkla (legalism) ilgili birtakım şeylere sahip olmayı gerektirirken; "iyi hukuk devleti", kişisel özgürlük, insan onu$r u$, insan hakları gibi değerlere saygilı devlet anlamına gelir ${ }^{17}$. Marmor'ın benim-

7 Waldron, Jeremy (2006) "The Rule of Law", The Stanford Encyclopedia of Philosophy, Zalta, Edward N. (ed.), https://plato.stanford.edu/entries/rule-of-law/, s.e.t. 18. 11. 2018; bkz. Uygur, s. 1156.

Bkz Raz, Joseph (1979) The Authority of Law, Oxford University Press, s. 214 vd.

Waldron, Jeremy (2006) "The Rule of Law", The Stanford Encyclopedia of Philosophy, Zalta, Edward N. (ed.), https://plato.stanford.edu/entries/rule-of-law/, s.e.t. 18. 11. 2018.

10 Zanghellini, Aleardo (2017) "The Foundations of Rule of Law", Yale Journal of Law and the Humanities, Vol. 28, Issue 2, s. 214 vd; Bkz. Tamanaha, s. 92; Craig, s. 477; Radin, s. 787; Uygur, s. 1156.

Cass, Ronald A. (2003) The Rule of Law in America, The Johns Hopkins Paperbacks Edition, s. 1- 2.

Cass, s. 1.

Cass, s. 2.

Cass, s. 2.

Ökçesiz, Hayrettin (1998b) "Hukuk Devleti Olgusu”, Hukuk Devleti, Ökçesiz, Hayrettin (Editör), Hukuk Felsefesi ve Sosyolojisi Arkivi 4, (HFSA), İstanbul, AFA Yayıncılık, s. 46.

16 Marmor, s. 666.

17 Marmor, s. 666. 
sediği hukuk devleti, yasalarm ilan edilmesi ve genel olması gereği gibi belirli biçimsel özelliklere sahip yasacılık (legalism)'tır ${ }^{18}$. Kelsen ise, devleti bir sosyal gerçeklik olarak hukuktan ayrı görmediği için hukukla yönetilen devlet" tanımlamasını saçma görmektedir'19. Çünkü Kelsen'e göre "hukukla yönetilmeyen devlet" hayal edilemez ${ }^{20}$. Ona göre her devlet bir hukuk düzeni olduğuna göre, hukukla yönetilmesi ve dolayısıyla hukuk devleti (rechtsstaat) olması kaçınılmazdır ${ }^{21}$. Buradan anlamamız gereken, Kelsen'de hukuk devletinin yasacllıktan (legalism) başka bir şey olmadığıdır. Ancak Kelsen'de basit bir yasacılık (legalism), söz konusu değildir. Çünkü onun teorisinde hukuk düzeni hiyerarșik ve mantıksal tutarlılığı olan bir yapıdır ${ }^{22}$. Pozitivist teorilerin biçimsel anlamda hukuk devleti anlayışına daha yakın durmaları, hukuku, içerik bakımından değil, biçimsel özellikleriyle tanımlamaya çalışmalarından kaynaklanır ${ }^{23}$. Hukuki pozitivizmin soy ağacı tezine göre, bir kuralın toplumdaki hukukun kaynağı ile bağlantısı kurulabiliyorsa, o kural geçerlidir ${ }^{24}$. Kuralın adil olup olmaması kuralın varlığı ve geçerliliği için önemli değildir ${ }^{25}$. Genelde doğal hukuk teorileri ise (Lon L. Fuller hariç) hukuku içerik bakımından tanımladıkları için, hukuk devleti bakımından da içeriği esas alan maddi (substantive) hukuk devleti teorilerini esas alırlar ${ }^{26}$. Ancak bütün doğal hukukçu teorisyenlerin maddi anlamda hukuk devletini kabul ettiğini söyleyemeyiz. Aşağıda görüleceği gibi Fuller doğal hukukçu olmasına rağmen hukuk devleti tanımı için biçimsel ölçütler üzerinde durmuştur. Yine aynı şekilde pozitivist hukuk teorilerinin karşısında olan herkesin maddi anlamda hukuk devletinden yana olacağını da iddia edemeyiz. Örneğin, Hayek pozitivist teorilere uzak dursa da genelde biçimsel/prosedürel hukuk devleti kampında görülür ${ }^{27}$. Ancak Hayek'in kabul ettiği hukuk teorisi göz önüne alınırsa konu tartışmaya açık hale gelir. Aşağıda bu konuyu tartışacağız.

Hukuk devleti kavramı, bazıları için asgari birtakım biçimsel koşulları ifade etse de, bazıları için hak ve adalet gibi zenginleştirilmiş içeriğe sahip bir program anlamına gelir. Hangi tanım ve içerikten yana olursak olalım, hukuk

\footnotetext{
Marmor, s. 666.

Kelsen, Hans (2005) Pure Theory of Law, (Translated from Second Revised and Enlarged German Edition. Translator: Knight, Max), Fift Printing, New Jersey, The Law Book Exchange, s. 312.

20 Kelsen, (2005), s. 312.

21 Kelsen, (2005), s. 313.

22 Bkz. Kelsen, (2005), s. 205 ve 221.

23 Curzon, L. B. (1995) Jurisprudence, Second Edition, Cavendish Publishing, s. 109.

24 Himma, Kenneth Einar (1999) “The Epistemic Sense of Pedigree Thesis", Pasific Philosophic Quarterly, Vol. 80, s. 46 vd.

25 Kelsen, Hans (1949) General Theory of Law and State, (Translator: Wedberg, Andres), Third Printing, Harvard University Press, s. 5 vd.; Austin, John (1995) The Province of Jurisprudence Determined, Rumble, Wilfrid E. (Editor), Cambridge University Press, s. 157; bkz. Parker, Reginald (1956) "legal Positivism", Notre Dame Law Review, Vol. 32, issue 1, s. 34-35

26 Bkz. Zanghellini, s. 14. Vd; Marmor, s. 667.

27 Bkz. Tamanaha, s. 93; Rose, s. 459.
} 
devleti ulaşılması gereken bir ideali gösterir. Hayek, hukuk devletini, "hukuk ötesi bir öğreti veya politik bir ideal” olarak görmektedir ${ }^{28}$. Raz da aynı şekilde hukuk devletini bir hukuk sisteminin az veya çok sahip olabileceği politik bir ideal olarak değerlendirir ${ }^{29}$. Marmor, hukuk devletini, "hukukla yönetilmenin iyi bir şey olduğu” biçiminde ahlaki-politik bir ideal olduğunu söyler ${ }^{30}$. Lyons, hukuk devletini, hukuki süreçlerdeki değerler olarak ele alırken ${ }^{31}$, süreçlerdeki bu değerleri bir $\operatorname{taraftan}^{32}$ ideal bir yasa koyucuyu betimlemeleri anlaminda "arzu edilen bir ideal", diğer yandan da hukukun uygulanmasıyla ilgili süreçsel (prosedürel) değerlerle ilgili bir ideal olarak kavrar ${ }^{33}$. Dolayısıyla hukuk devleti idealinin uygulamaya mükemmel bir şekilde yansıması arzu edilse bile bu çoğu zaman mümkün olmaz ${ }^{34}$. Ancak hangi hukuk devleti kavramını idealleştireceğimiz önem arz eder. Minimalist bir anlayış, hukuk devleti için asgari bazı şartları yeterli görerek kavramın mütevazı sınırlar içinde tutulmasından yana tavır alır. Daha iddialı (maximalist) bir yaklaşım, hukuk devletinin hak ve adalet gibi birtakım değerlerin gerçekleştirilmesine hizmet eden bir ideal olarak görür. Diğer bir yaklaşım, hukuk devletini biçimsel bir yapıdan içeriğe doğru zenginleşen bir ideal olarak görülmesi biçimindedir. Bu üç yaklaşımın yöntem ve iddiaları birbirinden farklıdır. Hukuk devleti kavramının teorik düzeyde farklılaşmasının nedeni, bu kavramın içeriğinin nasıl doldurulduğuyla alakalıdır ${ }^{35}$. Genel olarak hukuki pozitivistler, hukuku biçimsel özellikleriyle tanımladıkları için hukuk devleti anlayışları da buna yakındır. Bunun istisnaları olabilir. Örneğin Fuller, doğal hukuk teorisini benimsemesine karşın, biçimsel anlamda bir hukuk devleti anlayışını benimser. Ancak daha yakından bakıldığında, bunun yine Fuller'ın hukuk kavramıyla alakalı olduğu görülür. Çünkü Fuller, prosedürel (biçimsel) nitelikli bir doğal hukuk anlayışına sahip-

\footnotetext{
Hayek, F. A. (1990) The Constitution of Liberty, London, Routlege, s. 206.

Raz, s. 211.

Marmor, s. $666 \mathrm{vd}$.

Lyons, David (1984) Ethics and the Rule of Law, Cambridge University Press, s. 94.

Lyons, s. 200.

Lyons, s. $200 \mathrm{vd}$.

Raz, s. 222.

Marmor, "hukuk devleti hakkındaki bir teorinin hukukun niteliği hakkındaki bir teoriyle metodolojik ilişki içerisinde olduğunu" (Marmor, s. 667) tespit ettikten sonra, buna karşı gelenler olduğunu ve bu karşı gelmelerin de bir dereceye kadar doğru olduğunu söyler. (Marmor, s. 667). Marmor'a göre hukuk devletini anlayabilmek için ihtiyacımız olan şey, herhangi bir yönetim biçiminin hukuk devleti (legal) olabilmesi için zorunlu birtakım özellikleri taşımasının gerekli olduğu düşüncesidir. (Marmor, s. 668.)
} 
tir; hukuku içeriği ile tanımlamaz ${ }^{36}$. Fuller'ın pozitivistlerle arasındaki fark, ayrılabilirlik tezini reddederek hukuk devletinin nitelikleriyle hukuk kavramı arasında zorunlu ilişki kurmuş olmasıdır ${ }^{37}$.

\section{II- HUKUK DEVLETİ İDEALİNI BESLEYEN İLKELERİN NITTELİĞİ}

İster biçimsel anlamda olsun, ister maddi anlamda olsun hukuk devletini besleyen ilkeler/kurallar, "ilk düzen ilkeleri” değil, "ikinci düzen ilkeleri" dir $^{38}$. Hart bu tür ilkeleri, "ikincil kurallar" (secondary rules) sinıflandırmasına dâhil eder ${ }^{39}$. Bunun anlamı, ikincil düzene ait bu ilkelerin/kuralların, davranışlarımızı doğrudan düzenleyen ilk düzen ilkeleriyle/kurallarıyla ilgili olmalarıdır ${ }^{40}$. Yani ikincil kurallar davranışlarımızı doğrudan düzenlemez; bu kurallar, özel kişilere de yetki verse de çoğunlukla yasama organı ve yargı gibi iktidarı kullanan resmi yetkililere hitap eder ${ }^{41}$. İkinci düzen kuralları/ilkeleri, çoğunlukla resmi yetkililerin, ilk düzen kurallarını (primary rules) hangi içerikte yapacakları, onları nasıl değiştirecekleri ve bu ilk düzen kurallarının ihlali halinde yargılamanın nasıl yapılması gerektiğini düzenleyen kurallardır ${ }^{42}$. Hart bu ikinci düzen ilkelerini, ikincil kurallar olarak üç gruba ayırır. Birinci grubu, tanıma kuralları (rules of recognition) oluşturur. Tanıma kuralı, birincil kuralların hangi ölçütlere göre yapılması gerektiğine ilişkin geçerlilik şartlarını belirler ${ }^{43}$. Maddi anlamda hukuk devleti bakımından tanıma kuralı, ilk düzen niteliğindeki (birincil kurallar niteliğindeki) hukuk kurallarının hangi içerikte yapılması gerektiğini belirler. Örneğin cinsiyet ayırımına ilişkin yasa yapılmaz niteliğindeki bir anayasa hükmü ilk düzen ilkesi/kuralı (ikincil kural) olarak yasa koyucuya hitap eder. İkinci grubu, değiştirme kuralları (rules of change) oluşturur. Yasaların kim tarafından nasıl değiştirileceğine ilişkin

36 Bkz. Fuller, Lon L. (1969) The Morality of Law, Revised Edition, Yale Uiniversity Press s. 96 vd; Aktaş, Sururi (2011) Prosedürel Doğal Hukuk: Lon L. Fuller'ın Hukuk Kavramı, 1. Baskı, Ankara, XII Levha Yayın1, s. 10- 11

37 Bkz. Raz, s. 224, Aktaş (2011), s. 73 vd.

38 Summers, Robert S. (1999) "Principles of the Rule of Law," Notre Dame L. Rev. Vol. 74, Issue 5, s. 1692 vd.

39 Hart, H.L.A. (1994) The Concept of Law, Second Edition, with a postscript by Bulloch, Penelope A. / Raz, Joseph (Editors), Oxford, Clarendon Press s. 98; Bayles, Michael D. (1992) Hart's Legal Philosophy, Netherlands, Kluwer Academic Publishers, s. 58.

40 Hart, s. 94.

41 Hart, s. 41-42.

42 Bkz. Summers (1999), s. 1692 vd; Işıktaç, Yasemin (2006) Hukuk Felsefesi, 2. Bask1, İstanbul, Filiz Kitabevi, s. 352.

43 Bkz. Hart, s. 100 vd.; Şahin Ceylan, Şule (2014) H.L.A Hart'in Hukuk Kavramı, 1. Baskı İstanbul, XII Levha Yayını, s. 117. 
düzenlemeler getiren değiştirme kuralları ${ }^{44}$ da iktidarı kullanan siyasi iradeye veya yine yasa koyucuya hitap eder. Üçüncü grubu oluşturan muhakeme/yargılama kuralları da (rules of adjudication), yargılamanın hangi mahkeme tarafından ve nasıl yapılacağına ilişkin düzenlemeler getirir ${ }^{45}$. Bu kurallar da yine hukuku uygulayan resmi yetkililere/mahkemelere hitap eder.

Görüldüğü gibi hukuk devleti idealini besleyen kurallar, "sözleşmedeki borcunu yerine getirmelisin”, "yalan yere şahitlik yapmamalısın”, gibi ilk düzen kurallarıyla (birincil kurallarla) alakalı değildir. İlk düzen kuralları doğrudan davranışlarımızın nasıl olması gerektiğiyle ilgili kurallar oldukları halde, hukuk devletini besleyen ikinci düzen ilkeleri/ikincil kurallar çoğunlukla iktidarı kullanan resmi yetkililere yöneliktir. Hart'ın tespitine göre birincil kurallar ilkel toplumlar dahil her toplumda bulunmalarına karşın, bu ikincil kurallar daha sonra ortaya çıkmıştır ${ }^{46}$. İlkel toplumlarda ikincil kurallar ya çok zayıftır, ya da yoktur. Bundan dolayı ilkel toplumlarda hukuki belirlilik ve hukuk güvenliği yoktur veya çok azdır. Hart açısından, tekerleğin icadı medeniyetimiz için ne kadar önemliyse, ikincil kurallar da o kadar önemlidir ${ }^{47}$.

Hukuk güvenliği ve hukuki belirlilik hukuk devleti için kaçınılmaz niteliktedir $^{48}$. Hukuki belirliliği sağlayan kurallar ikincil kurallar arasındadır. Yasaların içeriğinin nasıl olması gerektiğine ilişkin tanıma kuralı da yine resmi yetkililere/yasa koyucuya hitap ettiği için maddi anlamda hukuk devletini sağlamaya dönüktür. Dolayısıyla gerek biçimsel anlamda hukuk devleti olsun gerekse maddi anlamda hukuk devleti olsun, hukuk devleti idealini besleyen kurallar Hart'ın ikincil kural dediği türdendir. Bu kurallar yasa yapımı ve keyfiliği ortadan kaldıracağı veya en azından azaltacağı için elzemdir. İkinci düzey kuralları (ikincil kuralları) zayıf olan hukuk sistemleri hukuk devleti ideali için güven vermeyen sistemlerdir.

İkincil kuralların olmadığı bir siyasi toplumda, birincil kurallar aralarında tutarlı ve mantıksal bir bütünlük oluşturamaz. İkincil kurallar yoksa, birincil kurallar birbiriyle tutarsız bir kurallar yığını niteliğini alabilir. Aynı

Hart, s. 95 vd.

Hart, s. 96-97.

Bkz. Şahin Ceylan, s. 111.

Hart, s. 42.

Köküsarı, İsmail (2005) Anayasa Hukukunda Hukuki Güvenlik İlkesi, Birinci Baskı, Ankara, Adalet Yayınevi, s. $21 \mathrm{vd}$. 
tanıma kuralına göre yapılan birincil kurallar arasında bir ahenk bulunur. Dolayısıyla ikincil kurallar yoluyla, birincil kurallar kendi aralarında tutarlı bir sistem oluşturur ${ }^{49}$. Kuralların bir sistem halinde yan yana bulunması hukuk güvenliği ve dolayısıyla hukuk devleti kavramı için gerekli bir koşuldur.

\section{III-BİÇIMSEL/PROSEDÜREL ANLAMDA HUKUK DEVLETİ}

Biçimsel ya da prosedürel anlamda hukuk devleti teorisi, hukuk devletinin varlığı için hukuk kurallarının içeriklerine dönük ahlaki bir sorgulamaya girmeksizin, ya kuralların taşıması gereken bazı nitelikleri ya da yasama, yürütme ve yargı erklerinin (mahkemelerin) izlemesi geren bazı prosedürleri koşul olarak ileri sürer. Örneğin yargılamaların önceden belirlenen usul kurallarına göre yapılması gereği bir prosedürken, kanunların genel olması gereği biçimsel bir niteliktir. İhtilafların önceden belirlenen mahkemelerde görülmesi ya da mahkemelerin önceden belirlenen prosedürleri (usulleri) takip etmesi gereği, hukuk devleti anlayışının yargıya dönük prosedürel ilkelerindendir. Yürütme organının düzenleyici işlem yaparken "genellik" ilkesine uyması ya da kazanılmış haklara saygı göstermesi ${ }^{50}$ de yürütme organına dönük hukuk devleti ilkelerindendir. Görüldügü gibi biçimsel/prosedürel anlamda hukuk devleti anlayışı, egemenliği kullanan üç erke (kuvvete) dönük biçimsel ya da prosedürel ilkeler öngörerek iktidarı sınırlamayı amaçlar.

Hukuk devleti kavramı yerine kullanabileceğimiz Amerikan hukukundaki due process kavramı da Prosedürel anlamda due process ve maddi anlamda due process olmak üzere ikiye ayrılmaktadır ${ }^{51}$. Prosedürel due process izlenmesi gereken bazı usul kurallarına işaret ederken ${ }^{52}$, maddi anlamda due process ise kararların içeriği ile ilgili bir ilkedir ${ }^{53}$. Biçimsel anlamda $d u e$ process, hak ve özgürlüklerin sınırlandırılması veya ortadan kaldırılması sırasında gerekli prosedür ve usüllerin izlenip izlenmediğini sorgularken, maddi anlamda due process, hak ve özgürlüklerin sınırlandırılması veya ortadan kaldırılma-

\footnotetext{
49 Şahin Ceylan, s. 114.

50 Bkz. Oğurlu, Yücel (2003) Kazanılmış Haklara Saygı ve Haklı Beklentiler Sorunu, Birinci Baskı, Ankara, Seçkin Yayını, s. 35 vd ve 39 vd.

51 Altıparmak, Kerem (1996) "Due Process Of Law" Kavramının Amerikan Hukukundaki Yeri Üzerine Bir İnceleme", Ankara Üniversitesi Hukuk Fakültesi Dergisi, Cilt. 45, sayı 1, s. 219-220; Scanlon, T.M. (1977) "Due Process", Due Process Nomos XVIII, Pennock, J. Ronald and Chapman, John W (Editors), New York University Press, s. 104 vd.

52 McGarry, James W. (1992) "Due Process", Rutgers Law Journal, Vol. 23, s. 846 vd; Grossi, Simona (2017) "Procedural Due Process", Seton Hall Circuit Review, Vol. 13, Issue 2, s. 155-202; Altıparmak, s. 219.

53 McGarry, s. 839; Altıparmak, s. 219.
} 
sında yeterli bir nedenin olup olmadığını sorgular ${ }^{54}$. Dolayısıyla maddi anlamda due process' in gereği olarak yasama organı dahi kanun yaparken, yeterli bir haklılaştırma nedeni olmadan hakları ortadan kaldıramaz ${ }^{55}$.

Tamanaha, biçimsel yaklaşımları, "kurallarla yönetilmek" (rule by law), "biçimsel yasallık" (formal legality) ve "demokrasi ve yasallık" olmak üzere üç bölüme ayırmaktadır ${ }^{56}$.

Biçimsel anlamda hukuk devletinin birinci basamağında kurallarla yöneltilmek gelmektedir. Kuralların taşıması gereken nitelikleri gözetmeksizin, sadece kurallarla yönetilmek biçimsel anlamda hukuk devletinin en basit ve en zayıf türüdür ${ }^{57}$. Belki bu özellik, Fuller tarafından hukuk devleti için önerilen ilkelerden sadece "kuralların genel olması" ${ }^{58 "}$ tanımlamasına denk düşmektedir. Çünkü Fuller, "kuralların genel olması”yla, kuralların çok sayıda kişiyi kapsaması şeklindeki genelliği kastetmiyordu. Fuller'ın genellikten kastı, kişisel kararlarla (decisions) değil, basitçe kurallarla yönetilmekti59 ${ }^{59}$ Aşağıda göreceğimiz gibi Fuller, hukuk devleti için başka nitelikler de öngörmektedir.

Hukuk devletinin bu türü, kişilerin kararlarına ve gelip geçici heveslerine göre değil, kurallarla idare edilmeyi buyurmaktadır. Kişilerin yönetimi değil, kuralların yönetimi ${ }^{60}$ dediğimiz ilke buna denk düşmektedir. Sellers de basit bir yasacillk (legalism) olan hukuk devletinin bu türünü, kendi iradesini pozitif hukuk yoluyla diğerlerine dayatan bir sistem olarak gördügü rechtsstaat'la ilişkilendirmektedir ${ }^{61}$. Tamanaha da hukuk devletinin bu zayıf türünü, kısmen rechtss-

54 Chemerinsky, Erwin (1999) “Substantive Due Porcess”, Touro Law Review, Vol 15, Issue 4, s. 1501.

55 Riggs, Robert E. (1990) "Substantive Due Process in 1791”, Wisconsin Law Review, Vol. 1990, Issue 4, s. 942; Örneğin Florida Yüksek Mahkemesi, Lite v. State davasında denetim altında olan maddeleri satan veya nakleden bir kişinin sürücü ehliyetinin geri alınmasına ilişkin bir yasayı Florida Anayasası'nın due process ilkesine aykırı bulmamıştır. (Bkz. Carolla, Amelia (1994) "Due Process", Rutgers Law Review, Vol. 25, s. 1093.

56 Tamanaha, s. 91.

57 Tamanaha, s. 92.

58 Fuller (1969), s. 46.

59 Fuller (1969), s. 47; bkz. Aktaş (2011), s. 18.

60 Kuralların önemi bakımından bkz. Gözler, Kemal (2018) Hukuka Giriş, 15 Baskı, Bursa, Ekin Yayını, s. 21 vd.

61 Sellers, Mortimar N.S. (2014) "What is the Rule of Law and Why is It So Important?", The Legal Doctrines of the Rule of Law and The legal State (Rechtsstaat), Vol. 38, Silkenat, James R./ Hickey, James H./ . Barenboim, Peter D, (Editors), Springer International Publishing, s. 4; Sellers'a göre Latince imperium Legum'dan gelen rule of law, hukuk sisteminin işleyişinde kişisel kararların etkisini azaltan bir düşünceyi içermektedir. (Sellers, s. 4); Özcan ise, haklar bakımından meseleye bakarak, rule of law'un hakların kaynağı bakımından yasa koyucuyu ikincilleştirdiğini, rechtsstaat'ın ise hakların kaynağı olarak yasa koyucuyu üstün gördüğünü söylemektedir. (Özcan, s. 233). Rosenfeld'e göre ise, Kant'ın felsefesinden kaynaklanan rechtsstaat anlayışı XIX. Yüzyılda pozitivist bir hale bürünmüştür. (Rosenfeld, Michel (2001) "The Rule Of Law And the Legitimacy Of Constitutional Democracy”, Southern California Law Review, Vol. 74, Issue 5, s. 1319) 
taat'a benzetmektedir" ${ }^{62}$. Yazarın analizine göre "XIX. yüzyılın ortalarından XX. Yüzyılın yarısına kadar rechtsstaat daha çok kurallarla yönetilmek" şeklinde anlaşıldığından hukuk yoluyla birçok vahşet ortaya çımıştır ${ }^{63}$. Chevallier'ın analizine göre, XIX. yüzyılın ilk yarısında doğal haklarla sinırlı devleti ifade eden rechtsstaat $^{64}$, Friedrich Julius Stahl'ın (1802-1861) Die Philishophie (1856) adlı eserinden sonra biçimsel hukuk devletini ifade etmek için kullanıldı ve Friedrih Geber (1823-1891), Paul Laband (1838-1918) ve Georg Jellinek'ten (1851-1911) sonra bu kavramın biçimci karakteri giderek yerleşmiş oldu ${ }^{65}$. Pfordten'e göre ise rechtsstaat, günümüzde rule of law gibi daha güçlü (thick) olarak tanımlanmaktadır ${ }^{66}$.

Biçimsel de olsa kurallar için herhangi bir nitelik aramayan ve yalnızca "kurallarla yönetilmek" anlayışına dayanan hukuk devleti, kişisel amaçlar için veya kötü amaçlar için kolayca kullanılabilir. Bundan dolayı Radbruch makalesine başlık olarak, "yasal haksızlık ve yasa üstü hukuk" tanımlamasını uygun görmüştür $^{67}$. Radbruch’a göre, “yasa, yasadır” formülü, hukukçuları (Almanya'da) yasalar ve keyfi güç karşısında çaresiz bırakmıştı ${ }^{68}$.

Biçimsel anlamda hukuk devletinin ikinci basamağında, belirli biçimsel birtakım niteliklere sahip kurallarla yönetilen devlet ${ }^{69}$ veya yönetim ve yargılamaya ilişkin belirli prosedürleri izleyen devlet anlayışı gelir. Yasaların belirli biçimsel özeliklere sahip olması, "iyi yasa yapımcıllğı"nın bir gereği olarak da tanımlanmaktadı $^{70}$. Bu anlayışta olanlar, hukuk devleti kavramı için, hukuk kuralların sahip olması gereken birtakım biçimsel şartlar öne sürerek, hukuk kurallarının içeriğini sorunsallaştırmaz. Lon L. Fuller ${ }^{71}$, A.V. Dicey ${ }^{72}$ ve Joseph Raz ${ }^{73}$ bu grupta yer alan en önemli yazarlardan sayılırlar. F. A. Hayek de hukuk devleti için birtakım biçimsel koşulları yeterli görse $\mathrm{de}^{74}$, kurallarının gelişimi bakımından adil

62 Tamanaha, s. 92

Tamanaha, s. 108.

Chevallier, Jacques (2010) Hukuk Devleti, (Çev. Gürcan, Ertuğrul Cenk), Ankara, İmaj Yayınevi, s.9.

Chevallier, s. 10; Ayrica bkz. Ökçesiz (1998a), s. 21 vd.

66 Von Der Pfordten, Dietmar (2014) "On the Foundations of the Rule of Law and the Principle of the Legal State/Rechtsstaat”, The Legal Doctrines of the Rule of Law and The legal State (Rechtsstaat), Vol. 38, Silkenat, James R./ Hickey, James H./ . Barenboim, Peter D, (Editors), Springer International Publishings, s. 24.

67 Radbruch, Gustav, (2006) "Statutory Lawlesness and Supra- Statutory Law", (Translator: Paulson, Bonnie L. and Paulson, Stanley L.), Oxford Journal of Legal Studies, Vol. 26, No. 1, s. 1-11.

68 Radbruch (2006), s. 6.

69 Tamanaha, s. $91 \mathrm{vd}$.

70 Köküsarı, s. 202 ve dipnot. 702.

71 Hukuk devletinin ilkeleri olarak niteleyebileceğimiz ilkeler için bkz. Fuller (1969), s. 46-70; Aktaş (2011), s.72. vd.

72 Dicey, A. V. (1979) Introduction to the Study of Law of the Constitution, Reprinted of (original) Tenth Edition, London, The Macmillan Press, s. 202-203.

73 Bkz. Raz, s. 210 vd.

74 Bkz. Hayek, F. A. (2006) The Road to Serfdom, London and New York, Routlege Classics, Published by Routlege. s. 75 vd; Bkz. Tamanaha, s. 93.vd; Aktaş, Sururi (2018) Hayek'in Hukuk Adalet Teorisi, 2. Baskı, Ankara, Liberte Yayını s. 166. 
davranış kurallarını yüceltmesi ve liberal değerleri adil hukuk için öncelemesi dikkate alınırsa, onun için farklı değerlendirme yapılabilir. Ancak biçimsel hukuk devleti kategorisi de kendi içerisinde çeşitli/farklı yaklaşımları barındırmaktadır.

Hukuk devleti ideali bakımından daha çok prosedürler üzerinde yoğunlaşan A.V. Dicey, anayasa hukukunun temel ilkelerinden biri olan hukuk devletinin üç anlamının olduğunu söyler ${ }^{75}$.

Birincisi, "yönetimin keyfiliğini, ayrıcalıklara sahip olmasını ve geniş takdir yetkisini engelleyen genel/olağan (regular) hukukun mutlak hâkimiyeti

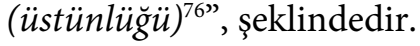

İkincisi, "yetkililerin ve diğer kimselerin hukuka itaat etmelerine ve olağan mahkemelerde yargılanmalarına muafiyet getirmeyi engelleyecek olan 'yasa önünde eşitlik veya olağan mahkemeler tarafindan uygulanan, ülkenin olağan hukukuna tüm sinıfların eşit olarak tabi olmasi ${ }^{77 ”}$, şeklindedir.

Üçüncüsü, “........yabancı ülkelerde bir anayasa kodu’nu oluşturan anayasa hukuku(kurallari), bizde (common law sisteminde)mahkemeler tarafindan tanımlanıp uygulanan hakların kaynağı değil, hakların bir sonucu oldu$\breve{g} u^{78 ”}$ ilkesidir.

Dicey, ikinci ilke ile idarenin ve idari görevlilerinin, vatandaşların tabi olduğu hukuktan başka bir hukuka ve başka bir yargı düzenine tabi olmalarının önüne geçmek istemektedir. Dicey, Fransa'da olduğu gibi vatandaşların tabi olduğu genel hukuktan ayrı olarak ayrı bir idare hukuku ve idari yargı düzeninin varlığını hukuk devletine aykırı bulduğu gibi, böyle bir düzeni İngiliz hukuk geleneği ile de bağdaştırmaz ${ }^{79}$. Ancak Dicey'in bu yaklaşımı mutlak anlamda doğru görünmüyor. Çünkü herkesin tabi olduğu genel hukukun yanında ayrı bir idare hukukun bulunması ve idari yargının ayrı bir yargı kolu olarak düzenlenmesi bir gelenek meselesidir ${ }^{80}$. İdari yargıyı ayrı bir yargı kolu olarak düzenleyen Kıta Avrupası ülkelerinin bu özelliklerinden dolayı hukuk devleti olamayacaklarını baştan söylemek doğru görünmüyor. Ancak, idarenin işleyişi ve sorumluluğunun temel adalet ilkeleriyle veya evrensel hukukla çelişecek şekilde düzenlenmesi hukuk devletiyle bağdaşmaz. Burada yapılması gereken idarenin etkililiği ile temel adalet ilkeleri arasında bir denge kurmak-

\footnotetext{
75 Dicey, s. 202-203; bkz. Principe, Michael L. (2000) “Albert Venn Dicey and the Principles of the Rule of Law: Is Justice Blind? A Comparative Analysis of the United States and Great Britain", Loyola of Los Angeles International and Comparative Law Review, Vol. 22:357, s. 359 vd; Craig, s. 470-474; Tamanaha, s. 63.

Dicey, s. 202; Craig, s.470; Rose, s. 458; Tamanaha, s. 63; Principe, s. 359.

Dicey, s. 202-203; bkz. Cairg, s. 472: Rose, 458; Tamanaha, s. 64; Principe, s. 359.

Dicey, s. 203; Cairg, s. 473, Rose, s. 458. Tamanaha, s. 64; Principe, s. 359.

Dicey, s. 202-203.

Bkz. Çağlayan, Ramazan, (2018), İdari Yargılama Hukuku, 10. Baskı, Ankara, Seçkin Yayını, s. 39 vd.
} 
tır. Daha etkili bir idari işleyiş için temel adalet ilkelerini zedelemek hukuk devletiyle bağdaşmaz.

Dicey'in hukuk devleti için öngördüğü ilkelerden ilk ikisinin biçimsel nitelikte olduğu görünmekle birlikte, üçüncü ilkenin biçimsel mi, yoksa maddi mi olduğu konusu tartışmaya açıktır. Bu ilkelerden üçüncü ilke, Dicey’in İngiltere için yaptığı bir tespittir. Dicey, bu ilkeyle, bireysel hakların kendi geleneklerinde, mahkeme kararlarıyla ortaya çıktığını belirtmektedir. Craig'ın da haklı olarak sorguladığı gibi, acaba bu ilkeden, hakların devlet iradesinden değil de, içtihatlarla ortaya çıtığı ve dolayısıyla bir sistemin hukuk devleti olabilmesi için bu haklara sahip olması gerektiğini savunmamıza yol açacak maddi anlamda hukuk devleti anlayışını çıkarabilir miyiz ${ }^{81}$ ? Craig, böyle bir sonuç yerine, hakların common law sisteminde daha iyi korunabildiği sonucunu çıkararak, bu ilkenin de maddi değil, yine biçimsel bir ilke olduğunu savunmaktadir ${ }^{82}$. Palombella ise, common law sisteminde, emsal kararlar, örfadet hukuku, gelenekler ve hakların hukuk devleti için önemli olduğuna işaret olarak Dicey'in bu üçüncü ilkesini göstermektedir ${ }^{83}$. Bundan dolayı common law sisteminde hukuk devletini kurumsal bir ideal olarak gören yazar ${ }^{84}$, bu sistemde hukuk devleti olarak ifade edilen rule of law'u, boş bir yasallık olarak nitelendirdiği rechtsstaat'tan ayrı görmektedir ${ }^{85}$. Ancak anlaşıldığı kadarıyla yazarın sözünü ettiği rechtsstaat, II. dünya savaşı öncesine denk düşen rechtsstaat'tır ${ }^{86}$. Dicey'in üçüncü ilkesi daha çok içeriksel ya da maddi bir ilke gibi durmaktadır. Çünkü, hakların kaynağı mahkeme içtihatları gösterilirken, bunlara, egemenin iradesi karşısında korunmuş bir alan sağlanmaktadır.

Biçimsel anlamda hukuk devleti ilkelerinin tipik bir görünümü Fuller’nn hukuk teorisinde görülür. Prosedürel nitelikte bir doğal hukuk teorisi geliştiren Fuller, hukukun içsel ahlakı (inner morality of law) diye nitelendirdiği yasallığın (legality) sekiz ilkesi olarak hukuk kuralların sahip olması gereken ilkeleri; (1) genel nitelikte olma, (2) ilan edilme (yayımlanma), (3) geriye yürümezlik (ileriye doğru yürürlük kazanma, (4) açıklık (belirlilik), (5) çelişmez-

Craig, s. 473.

Craig, s. 473.

Palombella, Gianluigi, (2010) "The Rule of Law as a Institutional Ideal", Rule of Law and Democracy: Inquiries into Internal and external Issues, Morlino, Leonardo and Palombella, Gianluigi (Editors), Sciulli, David (Series Editor) Volume 115, Leiden-Boston, Brill, s. 15.

84 Palombella, s. 3.

85 Palombella, s. 16.

86 Bkz. Palombella, s. 16. 
lik, (6) imkânsız olan yükümlülük getirmeme, (7) süreklilik (istikrar) ve (8) kurallarla, bu kuralların uygulanmalarının örtüşmesi "biçiminde saymıştır. ${ }^{87}$

Fuller bir hukuk devleti ideali oluşturma yerine, yukarıdaki ilkeleri prosedürel doğal hukukun ilkeleri olarak saymış ve hukukun içsel ahlakı olarak bu ilkeleri hukuk kavramıyla zorunlu olarak ilişkilendirmiştir ${ }^{88}$. Fuller açısından bu ilkelerin bir tanesi konusunda tam bir başarısızlık, ilgili hukuk sisteminin geçersizliğini gündeme getirecektir ${ }^{89}$. Raz, Fuller'in, ahlak (sekiz ilkenin oluşturduğu içsel ahlak) ile hukuk arasında zorunlu bir ilişki kurmasını eleştirmiştir ${ }^{90}$. Raz açısından bu ilkelerin yerine getirilmemesi, hukuk devletinin olmadığı anlamına gelse bile, ilgili hukuk kuralının geçersizliği sonucunu doğurmaz ${ }^{91}$. Bu da doğal hukukçu olan Fuller'la pozitivist olan Raz arasındaki en büyük farkı oluşturmaktadır.

Fuller'ın hukukun içsel ahlakı olarak tanımladığı sekiz ilke arasında kuvvetler ayrılığı, yargı bağımsızlığı ve yargısal denetim gibi unsurlar olmadığı için biçimsel anlamda hukuk devleti ideali bakımından eksik sayılabilir. Ancak Fuller'ın teorisinin hukuk devleti bakımından asıl eksikliği, hukuk kurallarının içeriği konusunda ahlaki bir denetim getirmekten kaçınmış olmasıdır. Daha açıkça ifade edilirse, Fuller'in içsel ahlakı, maddi anlamda hukuk devletinin gereklerini doğrudan kapsamamaktadır. Ancak Fuller'ın da belirttiği gibi bu sekiz ilkeye uyulmuş olması halinde dahi, hukuk kurallarının içeriğine dönük haksızlık ve adaletsizlik ihtimali azalacaktır ${ }^{92}$. Başka bir ifadeyle Fuller'ın sekiz biçimsel ilkesi hukukun içeriğine dönük doğrudan olmasa da dolaylı olarak bir denetleyici işlev görecektir.

Biçimsel anlamda bir hukuk devleti idealini ortaya koymaya çalışan Raz, tüketici olmayacak bir şekilde bazı ilkeleri şöyle sıralar ${ }^{93}$ :

87 Bkz. Fuller (1969), s. 46-91; Aktaş (2011), s. 16; Kramer, Matthew H. (2007) Objectivity and the Rule of Law, Cambridge University Press, s. 104 vd.

88 Sevel, Michael (2009), "Legal Positivism and Rule of Law", Australian Journal of Legal Philosophy, Vol. 34, s. 54; Aktaş (2011), s. 57 vd; Raz, s. 224.

89 Fuller (1969), s. 39; Sevel, s. 55.

90 Raz, s. 224; Sevel, s. 55.

91 Bkz. Raz, s. 224-225.

92 Fuller, Lon L. (1958) "Positivism and Fidelity to Law: A Reply to Professor Hart", Harvard Law Review, Vol. 71, No. 4, s. 636; Kramer, Matthew H. (1999) In Defence of Legal Positivism: Law Without Trimmings, Oxford University Press, s. 41 vd.; Aktaş (2011), s. 52-53.

93 Raz, s. 214-218. 
“(1) Bütün yasalar ileriye doğru yürürlü, açık ve belirli olmalıdır. (2) Yasalar göreli olarak istikrarlı olmalıdır. (3) Özgül yasaların (özgül hukuksal emirlerin) yapılması usulü, açık, istikrarl, belirli ve genel kurallara bağlanmalıdır. (4) Yargının bağımsızlı̆̆ı garanti edilmelidir. (5) Doğal adalet ilkeleri takip edilmelidir. (6) Mahkemelerin, hukuk devleti ilkelerinin yerine getirilmesi konusu üzerinde denetleyici yetkilere sahip olmaları gerekir. (7) Mahkemelere (adalete) ulaşım kolay olmalıdır. (8) Suçları önleyici birimlerin takdir yetkisi, hukuku bozacak şekilde düzenlenmemelidir"94.

Summers da görece (relatively) biçimsel bir hukuk devleti ideali geliştirmeye çalışmaktadır. Yazarın geliştirdiği görece biçimsel hukuk devleti ideali, kavramsal, kurumsal ve aksiyolojik ögelerden oluşur. Ancak yazar, kavramsal ögeyi diğerleri içerisinde eriterek, görece biçimsel hukuk devletinin bileşenleri olarak kurumsal ve aksiyolojik ögeler üzerinde durur ${ }^{95}$. Summers aç1sından hukuk devletinin kurumsal (kavramsal) bileşeni, bireylerarası ve bireylerle devlet arasındaki ilişkileri düzenleyen ilan edilmiş kuralların varlığı, bu kuralların bazı özelliklere sahip olması ve diğer bazı kurumsal gerekleri kap$\operatorname{sar}^{96}$. Bu kuralların hangi özelliklere sahip olması gerektiğini açıklarken Fuller'a atıf yapar. Yani Fuller'ın kurallarda aradığı özellikleri Summers da $\operatorname{arar}^{97}$. Summers, diğer bazı kurumsal şartlar olarak, kuralların görevliler ve diğerleri tarafından ihlali halinde uygulanacak yaptırımlar ve yasal çarelerin öngörülmesi, kuralların geçerliliği, yorumlanması ve uygulanmasıyla ilgili ihtilafların çıkması halinde, bu ihtilafların çözümünde gerekli usullerin (prosedürlerin) öngörülmesi $i^{98}$, yargıçların göreve kabul edilmesiyle ilgili prosüdürlerin belirlenmesi ve vatandaşları mahkemeler önünde savunacak bağımsız bir hukuk mesleğinin hukuken tanımlanması gereğinden söz eder ${ }^{99}$.

Summers, görece biçimsel hukuk devletinin aksiyolojik içeriği olarak, yukarıda saydığımız kurumsal ögelerin hizmet etmesi gereken bireysel otonomi, insan onuru ve eşit hukuki muamele gibi on bir madde halinde örnekseyici bir biçimde saydığı değerlerden (ilkelerden) söz etmektedir ${ }^{100}$. Bu değer-

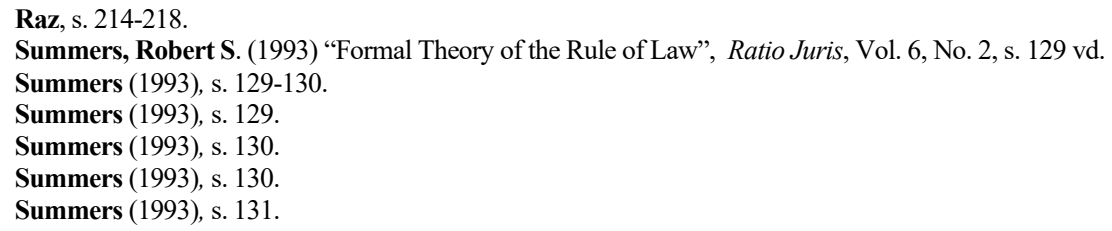


leri de örnekseyici olarak saydığını da dikkate alırsak, Summers'ın hukuk devleti, "görece biçimsel hukuk devleti" kavramını fazlasıyla hak eden ve maddi anlamda hukuk devleti idealine doğru kayan bir nitelik taşıdığını söyleyebiliriz.

Waldron, maddi anlamda hukuk devleti kavramına karşı olmamakla birlikte $^{101}$, hukuk devletinin biçimsel ve prosedür ilkeleriyle yetinir ${ }^{102}$. Çünkü Waldron açısından biçimsel ve prosedürel hukuk devleti ilkeleri, maddi anlamda hukuk devletiyle örtüşmektedir ${ }^{103}$. Yani Waldron, hukuk devletinin biçimsel ve prosedürel ilkelerinin yerine getirilmesi halinde, aslında maddi ilkelerin de gerçekleşeceğine inanır. Ancak Waldron, hukuk devleti için yasaların sadece bazı özelliklere sahip olması gerektiğini savunarak prosedürel ilkeleri ihmal ettiklerini söylediği Hayek ve Fuller gibi yazarların görüşlerini hukuk devleti için yeterli görmez ${ }^{104}$. Waldron hukuk devletinin biçimsel ilkeleri olarak Fuller'in sekiz ilkesini sayarken, adil yargılanma kuralları olarak niteleyebileceğimiz on adet de prosedürel ilke üzerinde durur. Bunlar:

(1) Delillere dayanan tarafsız bir mahkemede yargılanma, (2) hukuk eğitimi almış bağımsızlı̆̆ olan yargıçların oluşturduğu mahkemelerde yargılanma, (3) avukat tarafindan temsil edilme ve davaya hazırlanma zaman ve firsatına sahip olma hakkı, (4) yargılamanın önemli aşamalarında duruşmada hazır bulunma hakkı, (5) tanıklarla yüzleşme hakkı, (6) uygun denetimlerden geçerek elde edilmiş (hukuka uygun) delillere dayanılarak yargılanmanın garanti edilmesini isteme hakkı, (7) kişinin kendi lehine delil sunma hakkı, (8) delillerin ve davaya ilişkin hukuk normlarının etkililiğine karşı hukuki gerekçe sunma hakkı, (9) mahkemelerin verdiği kararın gerekçesini öğrenme hakkı, (10) üst mahkemeye başvurma hakkı" şeklinde özetleyebiliriz ${ }^{105}$.

Fuller'in sekiz ilkesiyle birlikte Waldron'ın bu prosedürel ilkeleri biçimsel anlamda görece daha güçlü bir hukuk devleti kavramını ortaya çıkaracak nitelikte görünmektedir. Waldron'ın prosedürel ilkeler üzerinde israr etmesi çok yerinde bir yaklaşım olmuştur. Çünkü hukuk devleti için yasaların sahip olması gereken özellikler yanında, onların uygulanması da önemli bir gerekli-

101 Waldron, Jeremy (2011) “The Rule of Law and Importance of Procedure”, NOMOS Vol. 50, Getting to the Rule of Law, Published by American Society for Political and Legal Philosophy, s. 4.

102 Waldron (2011), s. 5-6.

103 Waldron (2011), s. 4-5.

104 Waldron (2011), s. 7 vd.

105 Waldron (2011), s. 6. 
liktir. Yargının tarafsızlığı, bağımsızlı̆̆ı ve diğer adil yargılanma prosedürleri, hukuk devleti kavramının oluşturulmasında ihmal edilemez. Sadece ceza yargılanmasıyla ilgili değil, diğer yargılama alanlarında da, üzerinde ittifak bulunan yargılama ilke ve prosedürleri hukuk devletinin vazgeçilmez içeriğini oluşturur. Üzerlerinde ittifak bulunan kabul edilmiş yargılama prosedürleri tatbik edilmiyorsa, hukuk kurallarının biçimsel ve maddi özellikleri ne olursa olsun hukuk devletini sağlamada yetersiz kalır.

Liberal değerlerin gerçekleşmesine olanak tanıyan Hayek'in hukuk devleti anlayışı da genelde biçimsel nitelikli hukuk devleti anlayışları içerisinde görülür ${ }^{106}$. Hayek'in the Road to Serfdom (ilk baskısı, 1944) adlı eserinde Planlama ve Hukuk devleti adlı bölümde biçimsel nitelikli hukuk devleti kavramı için klasik sayılabilecek ifadeler yer alır. Hayek'e göre özgür bir ülkeyi keyfi bir yönetimden ayıran en önemli özellik, özgür bir ülkede hukuk devletini oluşturan ilkelere riayet edilmesidir ${ }^{107}$. Burada yer alan ifadeler açısından Hayek'in hukuk devleti tanımı ise, "yönetimin (devletin) bütün eylemlerinde önceden ilan edilen sabit kurallarla bağlı olmasıdır ${ }^{108}$. Düşünür açısından "bu kurallar, otoritenin zorlayıcı gücünü belirli bir durumda nasıl kullanacağını önceden açı bir kesinlikte tahmin edebilmeyi ve bireylerin bu bilgiye dayanarak kendi işlerini planlayabilmelerini olanaklı kılar"109.

Hayek, The Constitution of Liberty (ilk baskısı 1960) adlı eserinde hukuk devleti idealini biraz daha ayrıntılandırarak söz konusu idealin gerekleri olarak, "(a) yasaların genel olması, ileriye doğru yürürlük kazanması, ve belirli (certainity) olmast ${ }^{110}$, (b) yasa önünde eşitliğe uygun olarak uygulanmasi ${ }^{111}$ (c) yargıç bağımsızlğ̆ını sağlayacak kuvvetler ayrılığının bulunması $\imath^{112}$ (e) kişiler ve mülkiyet üzerinde zor kullanmayı gerektirecek idari takdir hakkının yargısal denetiminin bulunması" ${ }^{\prime 13}$ şartları üzerinde durur.

Bkz. Raz, s. 210; Tamanaha, s. 93-94; Aktaş (2018), s. 166

Hayek (2006), s. 75.

108 Hayek (2006), s. 75; Raz, s. 210; Erdoğan, Mustafa (2017) Anayasal Demokrasi, Gözden Geçirilmiş 13. Baskı, Ankara, Siyasal Kitabevi, s. 97.

109 Hayek (2006), s. 75-76; Raz, s. 210.

110 Hayek (1990), s. 208; Ayrıca bu eserin Türkçe çevirisi için bkz. Hayek, F. A. (2013) Özgürlüğün Anayasası, (Çev. Çelikkaya, Yusuf Ziya), 1. Baskı, Ankara, Bingbang Yayınları, s. 315 vd; Erdoğan, s. 135.

111 Hayek (1990), s. 209; Erdoğan, s. 135.

112 Hayek (1990), s. 210.

113 Hayek (1990), s. 211; Erdoğan, s. 95. 
Hayek'in hukuk devleti telakkisinde, liberalizmin, “yasalar, özgül bir amaç taşımayıp, çeşitli amaçların izlenmesinde koordinasyon işlevi görür” biçiminde ifade edilen nötr bir hukuk kavramı yatar ${ }^{114}$. Böyle bir hukuk kavramı, bireylerin kendi hayat planlarını ve geleceklerini tasarlama özgürlügünü sağlar. Başka bir anlatımla, bu hukuk anlayışı, insanın bireysel otonomisinin korunmasinı gerektirir ${ }^{115}$.

Dyzenhaus, biçimsel/formalist hukuk devleti kavramını, nötr bir kültürden (culture of neutrality) hareket eden biçimsel hukuk devleti ve amaç empoze eden (culture of reflection) bir kültürden hareket eden biçimsel hukuk devleti diye ikiye ayırarak Hayek'i, nötr bir kültürden (culture of neutrality) hareket eden biçimsel hukuk devleti başlığı altına yerleştirir ${ }^{116}$. Dyzenhaus'un bu tespiti, Hayek'in liberal kimliğine uygun düşmektedir. Hukuk kurallarının sahip olması gereken özellikler açısından, Hayek'in, Kanun, Yasama Faaliyeti ve Özgürlük/ Law, Legislation and Liberty (ilk baskısı 1973) adlı eserinde üzerinde durduğu adil davranış kuralları, onun hukuk devleti anlayışı için vazgeçilmezdir. Hayek'te, önceden ilan edilmiş genel kuralların (adil davranış kurallarının) kişilere empoze edilecek özgül amaçları (istisnai durumlar hariç) söz konusu değildir ${ }^{117}$. Başka bir anlatımla Hayek'te adil davranış kuralları negatiftir ${ }^{118}$. Adil davranış kurallarının bu özelliği, bireylere seçim (tercih) imkânı sunarak insan onurunun korunmasına katkı sağlamaktadır. Dolayısıyla Hayek, her ne kadar biçimsel hukuk devleti anlayışına taraf olmuşsa da, bireylere yükümlülük getirecek, onlara özgül amaçlar dayatacak (gerekli asgari vergi gibi yükümlülükler istisna olmak üzere) bir hukuk anlayışından

114 Dyzenhaus, David (1999) "Recrafting the Rule of Law", Recrafting the Rule of Law: The Limit of Legal Order, Dyzenhaus, David (Editor), Oxford, Portland, Oragon, Hart Publishing, 1999, s. 8.

115 Tamanaha, s. 94.

116 Dyzenhaus, s. 8; Dyzenhaus, bu ayrıma koşut olarak formalist hukuk devleti kavramını, Hayek'in temsil ettiği sağ-kanat formalizmi ve W. E. Scheuerman'ın temsil ettiği sol-kanat formalizmi olarak ikiye ayırmaktadır. Dyzenhaus'a göre Hayekçi formalis hukuk devleti, belirli amaçları empoze etmeyip belirlilik üzerinde yoğunlaşırken, Scheuerman'ın sol-kanat formalizmi belirli amaçları gerçekleştirmeyi hedeflerken, yine de formalist kalmaktadır. (Dyzenhaus, s. 8). Oysa Hayek açısından özgül sosyal amaçları gerçekleştirmeye çalışan sosyal devlet anlayışının pozitif yasa kavramı hukuk devletiyle bağdaşmaz. Belirli sosyal politikaları gerçekleştirmek, temel haklara, örneğin mülkiyet hakkına dokunursa, bu Hayek açısından hukuk devletiyle uyuşmaz. (Bkz. Hayek (2006), s. 76-78); Ayrıca bkz. Yayla, Atilla (1993) Özgürlük Yolu, Hayek'in Sosyal Teorisi, Ankara, Turhan Kitabevi, s. 32 vd ve s. 47.

117 Hayek, F. A. (1995) Kanun, Yasama Faaliyeti ve Özgürlük, C.II, Sosyal Adalet Serabı, (Çev. Erdoğan, Mustafa) 1. baskı, Türkiye İş Bankası Kültür Yayınları s. 23 vd; Hayek, F. A. (1994) Kanun, Yasama Faaliyeti ve Özgürlük, C. I, Kurallar ve Düzen, (Çev. Yayla, Atilla), 1. Baskı, Ankara, Türkiye İş Bankası Kültür Yayınları, s. 168-170; Aktaş (2018), s. 136-139.

118 Hayek, (1995) s. 23-24. 
yana değildir. Dolayısıyla Hayek'te kurallar içerik bakımından belirli bir tarzda ise, inter alia negatif/nötr ve bireysel özgürlüğu kabul edilebilecek sınırlar dışında kısıtlamıyorsa, böyle kuralların önceden ilan edilip uygulanması hukuk devleti için sorun oluşturmayacaktır.

Hayek'e göre hukuk devleti bakımından yasallık (legality) zorunludur; ancak yeterli değildir; Yönetime (devlete) her istediğini yapacak sınırsız yetki veren bir sistem, yasal olabilir; ancak böyle bir sistem hukuk devleti idealiyle bağdaşmaz; dolayısıyla düşünür açısından yasaların belirli ilkelere uyması hukuk devleti ideali için bir zorunluluktur ${ }^{119}$. Hayek, The Constitution of Liberty (1960) adlı eserinde genellik ve eşitlik dışında biçimsel adalet kriterlerine sahip olmadığımız için, hukuk kuralları bireyin tamamen ilgi alanına giren hususlara müdahalede bulunmayıp, iki kişi arasındaki ilişkileri düzenlediği müddetçe hukuk devleti için bir sorun olmayacağını; yasalar gayri adil ve kötü olsa bile, genellik ve eşitlik, adaletsizliği ve kötülüğü asgariye indireceğini ifade eder ${ }^{120}$. Hayek, hukuk devleti ideali için yasaları içerik bakımından bir teste tabi kılmak istemese de, yine de bu inancı için, yasaların, bireyin tamamen özel nitelikteki alanına müdahalede bulunmamasını şart koşar. Bu da içeriğe dönük bir sınırlama anlamına gelir. Kaldı ki The Constitution of Liberty adlı eserinden sonra 1973'de kaleme aldığı Law, Legislation and Liberty (Kanun, Yasama Faaliyeti ve Özgürlük) adlı eserinde, yasaların genel olarak negatif kalması gerektiğini savunarak, yükümlülük getirmeyi (pozitif olmayı) istisna olmaktan çlkarıp genel kural haline getirmeyi eleştirmektedir. Hayek'i her ne kadar biçimsel hukuk devleti başlığı altında değerlendirsek bile, eserlerini bir arada bir kül halinde değerlendirdiğimiz zaman, onun, mutlak anlamda biçimci bir hukuk devletinin kalıplarına sığmayacak bir hukuk teorisi geliştirdiğini söyleyebiliriz.

İrdelenmesi gereken hususlardan birisi de hukuk devleti ve demokrasi ilişkisidir. Müzakereci demokrasiyle ahlak ve hukuku temellendirmeye çalışan Habermas, hukuk devleti ile demokrasi arasındaki ilişkinin rastlantısal değil, zorunlu olduğunu söyler ${ }^{121}$. Bu yaklaşım açısından, demokrasi olmadan, hukuk devletinin gerçekleşmesi imkân dâhilinde değildir. Ancak demokrasi, hukuk devletinin çok önemli bir teminatı olmasına karşın, demokrasi ile hukuk devleti ideali arasında

\footnotetext{
119 Hayek, (1990), s. 205.

120 Hayek, (1990), s. 210.

121 Habermas, Jürgen (1996) Between Facts and Norms: Contributions to a Discourse Theory of Law and Democracy, (Translater: Rehg, William), Second Printing, The MIT Press, s. 449.
} 
kavramsal ve tanımsal zorunlu bir bağ görünmüyor. Kavramsal olarak demokrasi ile hukuk devleti ideali farklıdır. Daha açık bir ifade ile, hukuk devleti demokrasiden hareketle tanımlanamayacağı gibi, demokrasi de hukuk devleti kavramından hareketle tanımlanamaz. Demokrasi, hukuk devletinin garantisidir. Demokrasiye dayanmayan hukuk devleti düzenlerinin çok kolayca bozulacağı kuşkusuzdur. Ancak yine de demokrasi ile hukuk devleti arasında tanımsal ve kavramsal açılardan bir ilişki kurulamaz. Demokratik olmayan hukuk devleti örneği zayıf da olsa ihtimal dâhilindedir. Biçimsel anlamda bir hukuk devletini benimseyen Raz, demokratik olmayan hukuk sistemlerinin hukuk devletinin gerekleriyle bağdaşabileceğini söyler ${ }^{122}$. Dolayısıyla "demokratik" nitelemesi, hukuk devletine eklenen başka bir özelliktir. Türkiye Cumhuriyeti Anayasasının 2. maddesinde, "demokratik" sözcügü, "hukuk devleti" ibaresinin sıfatlarından birisidir. Federal Alman Cumhuriyeti Anayasasının 23/(1). maddesinde “demokratik" sözcüğü, hukuk devletinin sıfatı değil, hukuk devleti gibi ayrı bir ilke olarak yer almaktadır ${ }^{123}$. Demokrasi, hukuk devletini güçlendiren en önemli mekanizmadır. Ancak hukuk devleti ile demokrasi zorunlu olarak örtüşmez. Demokrasiyle hukuk devletini kavramsal olarak ayrı tutmak, demokratik olup da hukuk devleti olmayan hukuk sistemlerini fark etmemizi kolaylaştıracaktır. Demokrasi kavramı, kendisine çok sık göndermede bulunulan bir kavramdır. Bu kavramın yaygın bir referans noktası haline gelmesi, adalet kavramını ve hukuk devleti idealini gölgeleyen bir durumu ortaya çıkarmaktadır. Demokrasi varsa, hukuk devleti de zorunlu olarak vardır anlayışı, her zaman doğru değildir. Demokrasi ilkesine dayanan yasa koyucular, hukuk devletinin biçimsel koşullarını dahi sağlamayacak kurallar koyabilir. Sürekli bir biçimde geriye doğru yürüyen yasalar koymak, biçimsel hukuk devletiyle çok kolayca çelişebildiği halde demokrasiyle çelişmez. Tamamen halk iradesine dayanan bir yasa koyucu, herkesçe kabul edilebilen biçimsel hukuk devletinin niteliklerini ihmal edebilir. Demokrasi biçimsel hukuk devletinin niteliklerinin güvencelerini sağlayabilir; ancak zorunlu olarak onu garanti edemez. Demokratik ilkelerle belirlenmiş bir yasa koyucunun, geriye doğru yürürlüğü olan yasaları çıkarması zordur; ancak imkânsız değildir. Ancak anayasalarda, hukuk devleti

122 Raz, s. 211.

123 Türkiye Cumhuriyeti Adalet Bakanlığı web sayfasındaki Alman Anayasasının çevirisinde "demokratik" sözcüğü hukuk devletinin sıfatı olarak tercüme edilmişse de, bu orijinal metinle tam örtüşen bir çeviri değildir. Bkz. <http://www.adalet.gov.tr/duyurular/2011/eylul/anayasalar/anayasalar.htm>, s. e. t. 18.02.2019. 
idealinin demokrasi ile teminat altına alınması faydalı olabilir. Çünkü demokrasi olmadan hukuk devleti, rüzgârda fanusu olmayan alev gibidir; çabucak sönebilir.

\section{IV- MADDİ ANLAMDA HUKUK DEVLETİ KAVRAMI}

Maddi anlamda hukuk devleti anlayışı, hukuk kurallarının veya bir hukuk sisteminin sadece birtakım biçimsel, prosedürel ve kurumsal ilkelere sahip olmasıyla yetinmeyip, bunlara ek olarak hukuk kurallarının içeriksel olarak bazı özelliklere de sahip olması gerektiğini savunur ${ }^{124}$. Başka bir açıdan maddi anlamda hukuk devleti, hukukun tanımı bakımından hukuki pozitivizmin terk edilerek, belirli değerlere dayanan bir hukuk kavramının benimsenmesidir ${ }^{125}$. Kimi yazarlar, maddi hukuk devletinin koşulu olarak insan haklarının korunmasını şart koşarken ${ }^{126}$, kimisi, insan onuru ${ }^{127}$, bazıları toplumun ortak iyisini/kamu yararını (comon good/res publica) esas alır"128, kimisi ise "sosyal olmayı" temel alır ${ }^{129}$.

Tamanaha'nın tespit niteliğindeki analizinde maddi anlamda hukuk devletinin bileşenleri zayıftan güçlüye doğru, "bireysel haklar, insan onuru ve/veya adalet ve sosyal refah" olarak siralanır ${ }^{130}$. Tamanaha'nın bu analizinde ikinci ve üçüncü sırada gelenler bir öncekileri de içermektedir; sıralama ileriye doğru gittikçe hukuk devletinin içeriği de zenginleşmektedir ${ }^{131}$.

Bingham, saydığı hukuk devleti ilkeleri arasında, "hukuk temel insan haklarına yeterli bir koruma sağlamalıdır" ilkesini de sayar ${ }^{132}$. Biçimsel hukuk devleti anlayışını reddederek daha güçlü (thick) bir hukuk devletinden yana tavır alan Bingham insan haklarını çiğneyen bir devleti, biçimsel hukuk devleti şartlarını taşısa bile, hukuk devleti olarak görmez ${ }^{133}$. Yazar, Uluslararası Barolar Birliği tarafından 06/07/2007 tarihinde Moskova'da yapılan toplantıdaki

124 Bkz. Tamanaha, s. 102.

125 Ökçesiz (1998), s. 25.

126 Bingham, Tom (2011) The Rule of Law, Penguen Books, s. 66-67.

127 Corey, Brettschneider (2011) "A Substantive Conception of the Rule of Law: Nonarbitrary Treatment and Limits of Procedure", NOMOS Vol. 50, Getting to the Rule of Law, Published by American Society for Political and Legal Philosophy 2011, s. 52 vd. 
Rusya Federasyonu Anayasa Mahkemesi başkanının yaptığı konuşmaya göndermede bulunarak, yasanın, devlet iradesiyle eş tutulması anlayışına dayanan hukukun, hukuk devleti için yeterli olamayacağını vurgular ${ }^{134}$. Bu toplantıda, zamanın Rusya Anayasa Mahkemesi Başkanı V.D. Zorkin, XX. Yüzyılda hukukun, devlet iradesiyle ve dolayısıyla mevzuatla eş anlamlı olarak kavrandığı Alman Nazizmi ile Sovyet Komünizmi gibi rejimlerde milyonlarca insanın öldüğü iki trajedinin yaşandığını söyler ${ }^{135}$. Hukukun özünün (içeriğinin) de önemli olduğunu söyleyen Zorkin, hukuk devleti için insan haklarının korunması üzerinde durur ${ }^{136}$.

Zanghellini, hukuk devleti için hukukun adil olması ve temel hakları koruması gerektiğini şart koşar ${ }^{137}$. Yazar bu şartların gerçekleştirilmesi açısından, hukuk devleti idealini, doğal hukuk kavramıyla irtibatlandırır ${ }^{138}$.

Radbruch, devletin kendisinin koyduğu hukukla bağlı olması gerektiği şeklindeki pozitivist anlayışı reddederek, devlete tekaddüm eden insan hakları ve doğal hukuk ilkelerine bağlı bir devleti, hukuk devleti olarak telakki etmektedir ${ }^{139}$. Radbruch açısından hukuk devleti, semantik hukuk anlayışıyla değil belirli bir hukuk idesiyle ilgilidir ${ }^{140}$. Yazar açısından hukuki pozitivizmin, hukuku, sadece güçle ilişkilendirmesi yetersizdir; "güç, hukukun cebir düzeni bakımından (must of compulsion) bir temeli sayllabilir; yükümlülük veya hukukun geçerliliği bakımından bir temeli sayılamaz ${ }^{141}$ ".

Aristoteles, doğru yönetim (hukuk devleti) biçimleri olarak, devletin, kim veya kimler tarafından yönetildiğine bakmaksızın, "ortak yarar” (kamu yararı) amacına bağlı olup olmadıklarını sorgular. Filozof açısından ortak yarara bağlı yönetimler, doğru (iyi) yönetim biçimleridir ${ }^{142}$. Ortak yarar kavramı, yasaların içeriğine ilişkin bir değerlendirmeyi gerektirdiği için maddi

134 Bingham, s. 67.

135 Zorkin, Valery (2007) "Rule of Law and Legal Awereness", The World Rule of Law Movement and Russian Legal Reform, Neate, Francis and Nielsen, Holly (Editors), The Moscow City Chamber of Advocates, s. 47; Bingham, s. 67.

136 Zorkin, s. 47 vd; Bingham, s. 67.

137 Zanghellini, s. 214.

138 Zanghellini, s. 214.

139 Radbruch, Gustav, (1998) "Hukuk Devleti”, Hukuk Devleti, Ökçesiz, Hayrettin (Çev. ve Editör), Felsefesi ve Sosyolojisi Arkivi 4, İstanbul, AFA Yayıncılık, s. 16.

140 Radbruch (1998), s. 16.

141 Radbruch (2006), s. 6.

142 Aristoteles, (1990) Politika (Çev. Tunçay, Mete), 3. Bası, İstanbul, Remzi Kitabevi, s.81; bkz. Zanghellini, s. 222. 
anlamda hukuk devletiyle alakalıdır. Aristoteles'in ortak yarar kavramı, Ortaçağda Skolastik düşüncenin öncüsü Thomas Aquinas ${ }^{143}$ tarafından ve daha sonra John Finnis gibi neo-Thomistler tarafından da kullanılmıştır ${ }^{144}$. Ancak ortak yarar kavramının, maddi anlamda hukuk devleti kavramının bir ölçütü olarak kabul edilebilmesi için, "ortak yarar” 1 araçsal bir şekilde, yasaların "belirli bir zümrenin yararını öncelememesi”, "herkesin yararına olacak şekilde formüle edilmesi” gereğini anlamalıyı. Yoksa, bireylerin, olağanüstü durumlar hariç, kendi yararlarının çok kolayca tümüyle bir tarafa atılıp, politik olarak oluşturulmuş amaçlar kümesi içerisinde eritilmesi anlamında bir "ortak çıkar” kavramı, hukuk devleti idealiyle bağdaşmaz. Elbette doğal felaket gibi bazı olağanüstü durumlarda bireyler, kendi yararlarını bir tarafa bırakıp ortak yarar için seferber edilebilirler. Ancak olağan durumlarda, bireyin otonomisinin, toplumun amacı içerisinde yok edilmemesi gerekir. Kamu yararı (ortak çıkar) kavramı ile maddi anlamda hukuk devletinin diğer bir gereği olan "bireysel otonomi” arasında gerilim vardır. Ortak yarar kavramı büyütüldüğü zaman, bireyin otonomisi küçülür. Toplum halinde yaşamanın asgari gereklerinin oluşturduğu kamu yararı dışında, bireyin doğal hukukun gereklerine bağlı olarak kendi yaşam planına sahip olması gerekir.

Maddi anlamda hukuk devletini savunanların bir kısmı, sosyal adalet idealini, hukuk devletinin ayrılmaz bir parçası olarak görürler ${ }^{145}$. Bu düşünce açısından sosyal haklar olmaksızın klasik haklar realitede çok şey ifade etmezler. Hukuk devleti asıl anlamını, sosyal haklarla pekiştirilmiş hukuk düzeninde bulur. Bu yaklaşım, maddi anlamda hukuk devletinin zengin bir içerikle (klasik ve sosyal haklarla) kavramsallaştırılması anlamına gelir.

Hayek ve Nozick gibi liberaller, sosyal adalet kavramının, gönüllülüğe aykırı olarak sosyal dayanışmayı zor (hukuk) yoluyla sağlamaya çalıştığı için mülkiyet hakkına ve dolayısıyla hukuk devletine aykırı bulurlar ${ }^{146}$.

143 Bkz. Aquinas, Thomas (1947) Summa Theologica, Treatise on Law, Of the Essence of Law, First Part of Second Part, Question 90, Art. 2, (Trans. Fathers of the English Dominican Province), Benzinger Bros. Edition. https://dhspriory.org/thomas/summa/FS/FS090.html\#FSQ90OUTP1 s.e.t. 10.07.2019.

144 Finnis, John (1980) Natural Law and Natural Rights, Oxford, Clarendon Press, s. 125, 272, 273 ve 353; ayrica bkz. Osina, Petr (2006) "John finnis on the Law and Justice", Studia Juridica, ročník 4, číslo 1, s. 124 vd; Westerman, Pauline C. (1998) The Disintegration of Natural Law Theory: Aquinas to Finnis, Brill, s. 263.

145 Bulut, Nihat (2009) Sanayi Devriminden Küreselleşmeye Sosyal Haklar, 1. Baskı, İstanbul, XII Levha, s. 59 vd, Ökçesiz (1998), s. 45 ve 55.

146 Hayek (1995), s. 100 ve 122-123; Nozick, Robert (2006), , Anarşi, Devlet ve Ütopya, (Çev. Oktay, Alişan), 2. Baskı, İstanbul, Bilgi Üniversitesi Yayınları, s. 223 vd. 
Huber, hukuk devleti ile sosyal devleti birbiriyle karşılaştırırken, hukuk devletini," toplumun devlete karşı korunması, sosyal devleti ise toplumun devlet aracıliğıyla korunması ${ }^{147}$ ” olarak tanımlar. Yazar açısından hukuk devleti ile sosyal devlet birbirinden farklı oldukları gibi aynı zamanda belli bir ölçüde de birbirinin zıddını oluştururlar ${ }^{148}$. Ancak buna rağmen Huber bu iki idenin birleştirilmesi gerektiğini savunarak hukuk devleti idealini sosyal devlet idealiyle teyit etmeye çalışır ${ }^{149}$.

Sosyal ve ekonomik dayanışma ahlaken karşı konulamaz bir ilkedir. Dolayısıyla sosyal adalet, amacı açısından ahlaken inkâr edilemez; fakat metodolojik olarak tartışmaya açıktır. Yaşlılık, engelli olma, kıtlık, açlık sınırının altına düşme gibi insan yaşamını tehlikeye sokacak ve aşırı zorlaştıracak insani durumlar hariç ekonomik dayanışmanın gönüllülük esasına dayanması hukuk devletinin gereği olarak yorumlanması gerekir. Doğal olarak hukuk devleti de dâhil hiçbir ilke, insan yaşamının üstünde değildir. Hukuk devleti de nihai olarak insan için vardır. İnsan yaşamı ve onurunun tehlikeye gireceği durumlarda kuşkusuz sosyal amaçlar lehine tercihte bulunulabilir. Ancak bu gibi insani durumları aşan sosyal amaçlı müdahalelerde sınır tanımamak hukuk devletine zarara verir. Sosyal devletin amacı olan sosyal dayanışma gönüllük esasına değil, hukukun cebrine dayandığından, ekonomik eşitliği sağlama niteliğindeki doğrudan müdahalelerin kapsam ve yoğunluk arttıkça, hukuk devleti o oranda zayıflamaya eğilimlidir.

Kanaatimize göre maddi anlamda hukuk devletinin en önemli özelliklerinden biri, kural olarak hukuk normlarının negatif karakterli olmasıdır ${ }^{150}$. Yani hukuk devletinde, istisnalar hariç hukuk normları yasakları belirtip, diğer alanları özgür iradenin tercihine bırakmalıdır. Bu düşüncenin bir gereği olarak, bireylere yükümlülük getirmek, kural değil, istisnai bir durumdur. Yükümlülük getirmede sınır tanımayan bir yasama politikasının savunulması düşünülemez. O halde, bu sınırı koyacak ilke, hukuk devleti ideali olmalıdır. Hukuk normlarının tamamen negatif olması savunulamaz. Vergi ve nafaka

147 Huber, Ernst Rudolf (1998) " Moden Endüstri Toplumunda Hukuk Devleti ve Sosyal Devlet" (Çev. Ansay, Tuğrul), Hukuk Devleti, Hukuk Felsefesi ve Sosyolojisi Arkivi, Ökçesiz, Hayrettin (Editör), İstanbul, AFA Yayını 4, s. 66.

148 Huber, s. 77.

149 Huber, s. 77-78.

150 Hayek, (1995), s. 61 ve s. 211-212'deki 9. dipnot; Smith, Adam (2002) The Theory of Moral Sentiment, Haakonssen, Knud (Editor), Cambridge University Press, s. 95-96. 
yükümlülüğü gibi toplumsal hayatın zorunlu gereksinimleri için hukuk kurallarının pozitif karakterli olması reddedilemez. Ancak bu tür kurallar, negatif kurallara göre bir hukuk sisteminde daha az yer tutmalıdır.

\section{SONUÇ: HUKUK DEVLETI KAVRAMI İÇİN BİR ÖNERİ}

Görüldügü üzere hukuk devleti ilkesi, çeşitli amaçlar çerçevesinde farklı şekillerde kavramsallaştırılan bir idealdir. Hukuk kavramına farklı bakışları yansitan hukuk teorileri, birbirinden farklı hukuk devleti idealine sahip olabilmektedir. Başka bir anlatımla, hukukun tanımına ilişkin düşünceler, aslında bir ölçüde kendi hukuk devleti ideallerini de tanımlamaktadırlar. Pozitivist hukuk kuramcıları (teorisyenleri) daha biçimsel hukuk devleti ideallerinden yana tavır alırken; doğal hukuk anlayışından hareket eden teorisyenler, biçimselliğe ek olarak maddi (içeriksel) birtakım koşulların varlığını hukuk devleti için gerekli görürler. Bu anlamda, zayıf ve güçlü hukuk devleti kavramlarından söz edebiliriz. Zayıf hukuk devleti kavramı, hukuk kurallarının, geriye yürümezlik (makable şamil olmama) gibi birtakım biçimsel özelliklere sahip olmasını hukuk devleti ideali için yeterli görürken, güçlü hukuk devleti anlayışı, insan hakları ve onuru gibi kuralların içeriğine dönük bazı haklılaştırmaları gerekli görür.

Biz, hukuk devleti kavramına, biçimsel (prosedürel) ve kurumsal gereklerin yanı sıra maddi alamda hukuk devletinin gereklerini de dâhil ederek görece olarak daha güçlü bir hukuk devleti anlayışından yana tavır alıyoruz.

Ancak çalışmanın içerisinden de anlaşıldığı gibi hukuk devleti kavramının içeriğini hangi biçimsel ilke ve değerlerin oluşturacağı üzerinde tam bir mutabakat yoktur. Bunun, tabii bir durum olarak karşılanması gerekir. Çünkü, hukuk devleti gibi idealler, benimsenen hukuki ve siyasi teorilere göre farklılık arz eder.

Hukuk devleti kavramı enflasyonuna yol açsa da yine de kendi yaklaşımımız açısından bir hukuk devleti kavramının gereklerine makalenin bu sonuç kısmında bir öneri olarak yer vermek istiyoruz. Hukuk devletinin kurumsal gerekleri genel olarak "biçimsel hukuk devleti” kategorisinde değerlendirilse de, biz, önemlerine binaen daha çarpıcı olmaları ve dikkat çekmeleri açısından hukuk devletinin kurumsal gereklerini biçimsel gereklerinden ayrı tutarak 
bir öneride bulunmak istiyoruz. Dolayısıyla bizim anlayışımız açısından hukuk devleti kavramı, biçimsel, kurumsal ve maddi ilkelerden meydana gelmelidir.

\section{Bir öneri niteliğindeki hukuk devletinin biçimsel ilkeleri olarak;}

(a) kurallarla yönetilmek, (b) istisnalar hariç kuralların genel nitelikte olması, (c) kuralların ilan edilmesi, (d)hukuki belirlilĭ̆in (hukuk güvenliğinin) sağlanması, (e)kuralların herkese eşit uygulanması, (f) İstisnai durumlar hariç kuralların geriye yürürlü olmaması, (f) Suçta ve cezada kanunilik ilkesinin olmasi;

\section{kurumsal İlkeleri olarak;}

(a)kuvvetler ayrılığııın olması, (b) mahkemelerin bağımsı olması, (c) yasama organını Anayasaya göre hukuken denetleyecek bir yargı mekanizmanın olması, (d) yerindelik hariç, idareyi hukuken denetleyecek bir yargı mekanizmasının olması, (e)yargılamaların, tabii hakim ilkesine uygun olarak önceden ilan edilmiş usul kurallarına göre yapılması , (f) yaygın kabul görmüşstandartlara göre hak arama yollarının asgari koşullarının garanti edilmesi gerekir;

\section{maddi ilkeleri olarak;}

(a) Pozitif hukukun, çok yaygın olarak kabul gören billurlarmış adalet ilkelerine açıkça aykırı olmaması, (b) Kural olarak hukuk normlarının negatif olması, toplumsal yaşamın zorunlu kılması halinde pozitif yükümlülük getiren normlara başvurulması, (c)yaygın olarak kabul görmüşstandartlara göre klasik insan haklarinın tanınması

Yukarıdan da anlaşıldığı üzere hukuk devleti kavramını, sadece biçimsel ve prosedürel ilkelerden ibaret görmüyoruz. Biçimsel ve prosedürel ilkeler, hukuk devletinin onsuz olmaz (sine qua non) şartlarını oluşturmasına karşın yeterli değildir. Asgari düzeyde de olsa, pozitif hukukun haklılık ve adilliğine ilişkin bir sorgulamanın yapılması hukuk devletinin gereklerinden olmalıdır. Maddi anlamda hukuk devletinin ilkelerini asgari düzeyde tutarak, bunlar üzerindeki belirsizlik iddialarını en aza indirilmesini hedefledik. Yukarıdaki önerimizden de görüleceği üzere bu maddi ilkelerden birincisi, pozitif hukukun, yaygın kabul görmüş adalet standartlarıyla çelişmemesidir. Yaygın kabul görmüş adalet ilkeleri, pozitivistlerin bile karşı gelemeyeceği şekilde billurlaşmıştır. Örneğin cezaların şahsiliği ilkesi, ceza adaletinin bir görünümü olarak 
karşı konulamaz bir sabitedir. Yaygın kabul görmüş insan hakları standartları için de aynı şey geçerlidir. Dolayısıyla yaygın olarak kabul görmüş adalet ve insan hakları standartlarının, hukuk devleti kavramının unsurları haline getirilmesi iddia edildiği gibi hukuk devleti kavramını belirsizleştirmez. Bugün temel adalet ilkeleri ve bazı temel insan haklarının standartları üzerinde yaygın bir uzlaşma vardır. Hukuk devleti kavramı açısından bunlar göz ardı edilemez.

Hukuk devleti kavramına ilişkin önerdiğimiz söz konusu ilkeler, doğal olarak mutlak değil, azaltılıp ya da çoğaltılabilir niteliktedir. Çalışmada da belirttiğimiz gibi hukuk devleti ulaşılması gereken bir idealdir. Bu ilkeleri gerçekleştirme oranında hukuk devleti idealine o nispette yaklaşılır. 


\section{KAYNAKÇA}

Aquinas, Thomas (1947) Summa Theologica, Treatise on Law, Of the Essence of Law, First Part of Second Part, Question 90, Art. 2, (Trans. Fathers of the English Dominican Province), Benzinger Bros. Edition. https://dhspriory.org/thomas/summa/FS/FS090.html\#FSQ90OUTP1 s.e.t. 10.07.2019.

Aktaş, Sururi (2018) Hayek’in Hukuk Adalet Teorisi, 2. Baskı, Ankara, Liberte Yayını.

Aktaş, Sururi (2011) Prosedürel Doğal Hukuk: Lon L. Fuller'ın Hukuk Kavramı, 1. Baskı, Ankara, XII Levha Yayını.

Altıparmak, Kerem (1996) "Due Process Of Law" Kavramının Amerikan Hukukundaki Yeri Üzerine Bir İnceleme”, Ankara Üniversitesi Hukuk Fakültesi Dergisi, Cilt. 45, say1 1, ss. 219-250.

Aristoteles (1990) Politika (Çev. Tunçay, Mete), 3. Bası, İstanbul, Remzi Kitabevi.

Austin, John (1995) The Province of Jurisprudence Determined, Rumble, Wilfrid E. (Editor), Cambridge University Press.

Bayles, Michael D. (1992) Hart's Legal Philosophy, Netherlands, Kluwer Academic Publishers.

Bingham, Tom (2011) The Rule of Law, Penguen Books.

Bulut, Nihat (2009) Sanayi Devriminden Küreselleşmeye Sosyal Haklar, 1. Baskı, İstanbul, XII Levha.

Carolla, Amelia (1994) “Due Process”, Rutgers Law Review, Vol. 25, pp. 1092-1106.

Cass, Ronald A. (2003) The Rule of Law in America, The Johns Hopkins Paperbacks Edition.

Chemerinsky, Erwin (1999) “Substantive Due Porcess”, Touro Law Review, Vol 15, Issue 4, pp. 1501-1534.

Chevallier, Jacques (2010) Hukuk Devleti, (Çev. Gürcan, Ertuğrul Cenk), Ankara, İmaj Yayınevi.

Corey, Brettschneider (2011) "A Substantive Conception of the Rule of Law: Nonarbitrary Treatment and Limits of Procedure", NOMOS Vol. 50, Getting to the Rule of Law, Published by American Society for Political and Legal Philosophy 2011, pp. 52-63.

Craig, Paul (1997) "Formal and Substantive Conceptions of The Rule of Law: An Analytical Framework", Public Law, pp. 467-487.

Curzon, L. B. (1995) Jurisprudence, Second Edition, Cavendish Publishing.

Çağlayan, Ramazan, (2018), İdari Yargılama Hukuku, 10. Baskı, Ankara, Seçkin Yayını.

Dicey, A. V. (1979) Introduction to the Study of Law of the Constitution, Reprinted of (original) Tenth Edition, London, The Macmillan Press.

Dyzenhaus, David (1999) "Recrafting the Rule of Law", Recrafting the Rule of Law: The Limit of Legal Order, Dyzenhaus, David (Editor), Oxford, Portland, Oragon, Hart Publishing, pp. 1-12. 
Erdoğan, Mustafa (2017) Anayasal Demokrasi, Gözden Geçirilmiş 13. Baskı, Ankara, Siyasal Kitabevi.

Finnis, John (1980) Natural Law and Natural Rights, Oxford, Clarendon Press.

Fuller, Lon L. (1958) "Positivism and Fidelity to Law: A Reply to Professor Hart", Harvard Law Review, Vol. 71, No. 4, pp. 630-672.

Fuller, Lon L. (1969) The Morality of Law, Revised Edition, Yale Uiniversity Press.

Gözler, Kemal (2018) Hukuka Giriş, 15. Baskı, Bursa, Ekin Yayını.

Grossi, Simona (2017) "Procedural Due Process", Seton Hall Circuit Review, Vol. 13, Issue 2, pp. 155-202.

Gül, Cengiz (2010) İktidarın Sınırlandırılması ve Hukuk Devleti, Birinci Baskı, Ankara, Adalet Yayınevi.

Habermas, Jürgen (1996) Between Facts and Norms: Contributions to a Discourse Theory of Law and Democracy, (Translater: Rehg, William), Second Printing, The MIT Press.

Hart, H.L.A. (1994) The Concept of Law, Second Edition, with a postscript by Bulloch, Penelope A./Raz, Joseph (Editors),Oxford, Clarendon Press.

Hatemi, Hüseyin (1989) Hukuk Devleti Öğretisi, 1. Baskı, İstanbul, İşaret Yayınları.

Hayek, F. A. (2006) The Road to Serfdom, London and New York, Routlege Classics, Published by Routlege.

Hayek, F. A. (1995) Kanun, Yasama Faaliyeti ve Özgürlük, C.II, Sosyal Adalet Serabı, (Çev. Erdoğan, Mustafa) 1. Baskı, Türkiye İş Bankası Kültür Yayınları.

Hayek, F. A. (1994) Kanun, Yasama Faaliyeti ve Özgürlük, C. I, Kurallar ve Düzen, (Çev. Yayla, Atilla), 1. Baskı, Ankara, Türkiye İş Bankası Kültür Yayınları.

Hayek, F. A. (2013) Özgürlügün Anayasası, (Çev. Çelikkaya, Yusuf Ziya), 1. Baskı, Ankara, Bingbang Yayınları.

Hayek, F. A. (1990) The Constitution of Liberty, London, Routlege.

Himma, Kenneth Einar (1999) "The Epistemic Sense of Pedigree Thesis", Pasific Philosophic Quarterly, Vol. 80, pp. 46-63.

Huber, Ernst Rudolf (1998) " Moden Endüstri Toplumunda Hukuk Devleti ve Sosyal Devlet" (Çev. Ansay, Tuğrul), Hukuk Devleti, Hukuk Felsefesi ve Sosyolojisi Arkivi, Ökçesiz, Hayrettin (Editör), İstanbul, AFA Yayını 4, ss. 57-81.

Işıktaç Yasemin (2006) Hukuk Felsefesi, 2. Baskı, İstanbul, Filiz Kitabevi.

Kelsen, Hans (1949) General Theory of Law and State, (Translator: Wedberg, Andres), Third Printing, Harvard University Press.

Kelsen, Hans (2005) Pure Theory of Law, (Translated from Second Revised and Enlarged German Edition. Translator: Knight, Max), Fift Printing, New Jersey, The Law Book Exchange. 
Köküsarı, İsmail (2005) Anayasa Hukukunda Hukuki Güvenlik İlkesi, Birinci Baskı, Ankara, Adalet Yayınevi.

Kramer, Matthew H. (1999) In Defence of Legal Positivism: Law Without Trimmings, Oxford University Press.

Kramer, Matthew H. (2007) Objectivity and the Rule of Law, Cambridge University Press.

Lyons, David (1984) Ethics and the Rule of Law, Cambridge University Press.

Marmor, Andrei (2010) “The Ideal of the Rule of Law”, A Companion to Philosophy of Law and Legal Theory, Patterson, Dennis, (Editor), Second Edition, Wiley-Blacwell.

McGarry, James W. (1992) “Due Process”, Rutgers Law Journal, Vol. 23, pp. 839-855.

Nowacki, Josef (1969) “The Material and Formal Conceptions of the Rule of Law", Polish Round 3, pp. 81-87.

Tamanaha, Brain Z. (2004) On The Rule Of Law: History, Politics, Theory, Cambridge University Press.

Nozick, Robert (2006), , Anarşi, Devlet ve Ütopya, (Çev. Oktay, Alişan), 2. Baskı, İstanbul, Bilgi Üniversitesi Yayınları.

Oğurlu, Yücel (2003) Kazanılmış Haklara Saygı ve Haklı Beklentiler Sorunu, 1. Baskı, Ankara, Seçkin Yayını.

Osina, Petr (2006) "John finnis on the Law and Justice", Studia Juridica, ročník 4, číslo 1, pp. 122-136.

Ökçesiz, Hayrettin (1998) "Hukuk Devleti Olgusu", Hukuk Devleti, Ökçesiz, Hayrettin (Editör), Hukuk Felsefesi ve Sosyolojisi Arkivi 4, (HFSA), İstanbul, AFA Yayıncılık, ss. 44-56.

Ökçesiz, Hayrettin (1998) "Hukuk Devleti”, Hukuk Devleti, Ökçesiz, Hayrettin (Editör), Hukuk Felsefesi ve Sosyolojisi Arkivi 4, (HFSA), İstanbul, AFA Yayıncılık ss. 17-34.

Özcan, Mehmet Tevfik (2008) Modern Toplum ve Hukuk Devleti, 1. Baskı, İstanbul, XII Levha Yayını.

Palombella, Gianluigi, (2010) "The Rule of Law as a Institutional Ideal", Rule of Law and Democracy: Inquiries into Internal and external Issues, Morlino, Leonardo and Palombella, Gianluigi (Editors), Sciulli, David (Series Editor) Vol. 115, Leiden-Boston, Brill, pp. 3-37.

Parker, Reginald (1956) "legal Positivism”, Notre Dame Law Review, Vol. 32, Issue 1, pp. 31-42.

Principe, Michael L. (2000) "Albert Venn Dicey and the Principles of the Rule of Law: Is Justice Blind? A Comparative Analysis of the United States and Great Britain”, Loyola of Los Angeles International and Comparative Law Review, Vol. 22:357, pp. 357-373.

Radbruch, Gustav, (1998) "Hukuk Devleti”, Hukuk Devleti, Ökçesiz, Hayrettin (Çev. ve Editör), Felsefesi ve Sosyolojisi Arkivi 4, (HFSA), İstanbul, AFA Yayıncılık, ss. 11-16. 
Radbruch, Gustav, (2006) "Statutory Lawlesness and Supra- Statutory Law", (Translator: Paulson, Bonnie L. and Paulson, Stanley L.), Oxford Journal of Legal Studies, Vol. 26, No. 1, pp. 1-11.

Radin, Margaret Jane (1989) "Reconsidering the Rule of Law", 69, Boston University Law Review, Vol. 69, No:4, pp.781-819.

Raz, Joseph (1979) The Authority of Law, Oxford University Press.

Riggs, Robert E. (1990) “Substantive Due Process in 1791”, Wisconsin Law Review, Vol. 1990, Issue 4, pp. 941-1005.

Rose, Jonathan (2004) "The Rule of Law in the Western World: An Overview", Journal Of Social Philosophy, Vol. 35, No. 4, pp. 457-470.

Rosenfeld, Michel (2001) "The Rule Of Law And the Legitimacy Of Constitutional Democracy", Southern California Law Review, Vol. 74, Issue 5, pp. 1307-1351.

Scanlon, T.M. (1977) “Due Process", Due Process Nomos XVIII, Pennock, J. Ronald and Chapman, John W (Editors), New York University Press, pp. 93-125.

Sellers, Mortimar N.S. (2014) "What is the Rule of Law and Why is It So Important?", The Legal Doctrines of the Rule of Law and The legal State (Rechtsstaat), Vol. 38, Silkenat, James R./ Hickey, James H./ Barenboim, Peter D, (Editors), Springer International Publishing, pp. 3-13.

Sevel, Michael (2009), "Legal Positivism and Rule of Law", Australian Journal of Legal Philosophy, Vol. 34, pp. 53-68.

Smith, Adam (2002) The Theory of Moral Sentiment, Haakonssen, Knud (Editor), Cambridge University Press.

Summers, Robert S. (1993) "Formal Theory of the Rule of Law", Ratio Juris, Vol. 6, No. 2, pp. 127-142.

Summers, Robert S. (1999) "Principles of the Rule of Law," Notre Dame L. Rev. Vol. 74, Issue 5, pp. 1691-1712.

Şahin Ceylan, Şule (2014) H.L.A Hart'ın Hukuk Kavramı, 1. Baskı İstanbul, XII Levha Yayını.

Tamanaha, Brain Z. (2004) On The Rule Of Law: History, Politics, Theory, Cambridge University Press.

Uygur, Gülriz (2013) Hukuk Devletinde Hukukun Önünde Olmanın Anlamı, Prof. Dr. Erdal ONAR’a Armağan, Cilt. II, Ankara, Ankara Üniversitesi Yayınları.

Von Der Pfordten, Dietmar (2014) "On the Foundations of the Rule of Law and the Principle of the Legal State/Rechtsstaat”, The Legal Doctrines of the Rule of Law and The legal State (Rechtsstaat), Vol. 38, Silkenat, James R./ Hickey, James H./ Barenboim, Peter D, (Editors), Springer International Publishing, pp.15-28.

Waldron, Jeremy (2006) "The Rule of Law", The Stanford Encyclopedia of Philosophy, Zalta, Edward N. (ed.) URL: https://plato.stanford.edu/entries/r ule-of-law/, s.e.t. 18. 11. 2018. 
Waldron, Jeremy (2011) "The Rule of Law and Importance of Procedure", NOMOS Vol. 50, Getting to the Rule of Law, Published by American Society for Political and Legal Philosophy, pp. 3-31.

Westerman, Pauline C. (1998) The Disintegration of Natural Law Theory: Aquinas to Finnis, Brill.

Yayla, Atilla (1993) Özgürlük Yolu, Hayek'in Sosyal Teorisi, Ankara, Turhan Kitabevi.

Zanghellini, Aleardo (2017) "The Foundations of Rule of Law", Yale Journal of Law and the Humanities, Vol. 28, Issue 2, pp. 213-240.

Zorkin, Valery (2007) "Rule Of Law And Legal Awereness", The World Rule Of Law Movement And Russian Legal Reform, Neate, Francis And Nielsen, Holly (Editors), The Moscow City Chamber Of Advocates, pp. 46-61. 